\title{
A Literature Survey to Identify Potentially Problematic Volatile lodine-Bearing Species Present in Off-Gas Streams
}

Fuel Cycle Research \& Development

Prepared for U.S. Department of Energy Material Recovery and Waste Form Development Campaign SH Bruffey (ORNL), BB Spencer (ORNL) DM Strachan (Strata-G), RT Jubin (ORNL), Nick Soelberg (INL), and BJ Riley (PNNL) 30 June 2015 FCR\&D-MRWFD-2015-000421

ORNL-SPR-2015/290 INL/EXT-15-35609 


\title{
DOCUMENT AVAILABILITY
}

Reports produced after January 1, 1996, are generally available free via US Department of Energy (DOE) SciTech Connect.

Website http://www.osti.gov/scitech/

Reports produced before January 1, 1996, may be purchased by members of the public from the following source:

\author{
National Technical Information Service \\ 5285 Port Royal Road \\ Springfield, VA 22161 \\ Telephone 703-605-6000 (1-800-553-6847) \\ TDD 703-487-4639 \\ Fax 703-605-6900 \\ E-mail info@ntis.gov \\ Website http://www.ntis.gov/help/ordermethods.aspx
}

Reports are available to DOE employees, DOE contractors, Energy Technology Data Exchange representatives, and International Nuclear Information System representatives from the following source:

Office of Scientific and Technical Information

PO Box 62

Oak Ridge, TN 37831

Telephone 865-576-8401

Fax 865-576-5728

E-mail reports@osti.gov

Website http://www.osti.gov/contact.html

\section{DISCLAIMER}

This report was prepared as an account of work sponsored by an agency of the United States Government. Neither the United States Government nor any agency thereof, nor any of their employees, makes any warranty, express or implied, or assumes any legal liability or responsibility for the accuracy, completeness, or usefulness of any information, apparatus, product, or process disclosed, or represents that its use would not infringe privately owned rights. Reference herein to any specific commercial product, process, or service by trade name, trademark, manufacturer, or otherwise, does not necessarily constitute or imply its endorsement, recommendation, or favoring by the United States Government or any agency thereof. The views and opinions of authors expressed herein do not necessarily state or reflect those of the United States Government or any agency thereof. 


\section{SUMMARY}

Four radionuclides have been identified as being sufficiently volatile in the reprocessing of nuclear fuel that their gaseous release needs to be controlled to meet U.S. regulatory requirements (Jubin et al. 2011, 2012). These radionuclides are ${ }^{3} \mathrm{H},{ }^{14} \mathrm{C},{ }^{85} \mathrm{Kr}$, and ${ }^{129} \mathrm{I}$. Of these, ${ }^{129} \mathrm{I}$ has the longest half-life and potentially highest biological impact. Accordingly, control of the release of ${ }^{129} \mathrm{I}$ is most critical with respect to U.S. regulations for the release of radioactive material in stack emissions. Current U.S. Environmental Protection Agency regulation governing nuclear facilities (40 CFR 190) states that the total quantity of radioactive materials entering the general environment from the entire uranium fuel cycle, per gigawatt-year of electrical energy produced by the fuel cycle, must contain less than $5 \mathrm{mCi}$ of ${ }^{129} \mathrm{I}$.

The study of inorganic iodide in off-gas systems has been almost exclusively limited to $\mathrm{I}_{2}$, and the focus of organic iodide studies has been $\mathrm{CH}_{3} \mathrm{I}$. In this document, we provide the results of an examination of publicly available literature that is relevant to the presence and sources of both inorganic and organic iodine-bearing species in reprocessing plants. We especially focus on those that have the potential to be poorly sequestered with traditional capture methodologies. These forms have historically been known as penetrating iodine-bearing species.

To understand the importance of capturing penetrating forms of iodine, a calculation of the overall plant decontamination factor (DF) was carried out by estimating the iodine splits, speciation and individual DFs for each off-gas stream within the Used Nuclear Fuel reprocessing plant. This analysis leads to several key observations. First, in spite of high decontamination factors (DFs) for treatment of the dissolver offgas (DOG), the losses to the head-end cell control the overall plant DF. Second, the vessel off-gas (VOG) DF may be limiting to the overall plant DF as it is the stream where penetrating, or difficult to remove, iodine species are most likely. Third, the contributions from penetrating forms of iodine to the plant DF are largely unknown; the overall plant DF depends strongly on the possible DF value that can be achieved for these penetrating forms at each off-gas stream. Closure of this knowledge gap would allow for better analysis of the contribution that penetrating forms of iodine may have on the overall plant DF. If their impact is determined to be limiting, development of new capture technologies may be required.

Based on the results of the literature survey and some limited thermodynamic modeling, the inorganic iodine species hypoiodous acid (HOI) and iodine monochloride ( $\mathrm{ICl}$ ) were identified as potentially lowsorbing iodine species that could be present in off-gas systems. Organic species of interest included both short chain alkyl iodides such as methyl iodide $\left(\mathrm{CH}_{3} \mathrm{I}\right)$ and longer alkyl iodides up to iodododecane $\left(\mathrm{C}_{10} \mathrm{H}_{21} \mathrm{I}\right)$. It was found that fuel dissolution may provide conditions conducive to HOI formation and has been shown to result in volatile short-chain and long-chain alkyl iodides although these may not volatilize until later in the reprocessing sequence. Solvent extraction processes were found to be significant sources of various organic iodine-bearing species; formation of these was facilitated by the presence of radiolytic decomposition products resulting from radiolysis of tri- $n$-butyl phosphate and dodecane. Primarily inorganic iodine compounds were expected from waste management processes, including chlorinated species such as ICl.

Critical knowledge gaps that must still be addressed include confirmation of the existence and quantification of low-sorbing species in the off-gas of reprocessing facilities. The contributions from penetrating forms of iodine to the plant DF are largely unknown and highly dependent on the magnitude of their presence. This report shows that penetrating iodine-bearing species may respond differently than elemental iodine to current capture technology. These species are likely to be more difficult to remove, and it is likely that their sequestration could be improved through the use of different sorbents, through design modifications of the off-gas capture system, or through chemical conversion prior to iodine abatement that would produce more easily captured forms. This type of research will be valuable in 
A Literature Survey to Identify Potentially Problematic Volatile lodine-Bearing Species Present in Off-gas Streams

determining the impact that potentially penetrating iodine species have on the DF of a reprocessing facility and will allow design of a facility that can provide the highest quality of iodine abatement. 


\section{CONTENTS}

SUMMARY iii

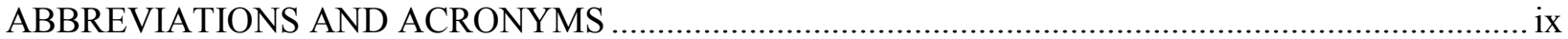

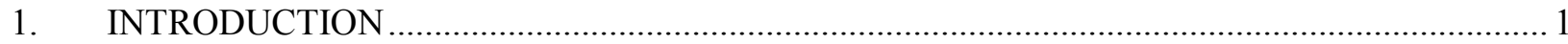

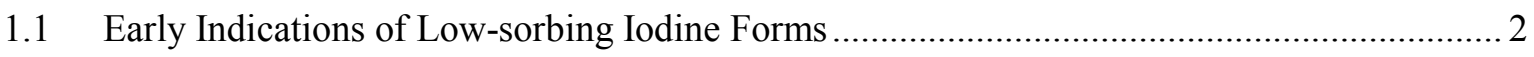

1.2 Importance of Understanding Low-sorbing Iodine Species................................................ 3

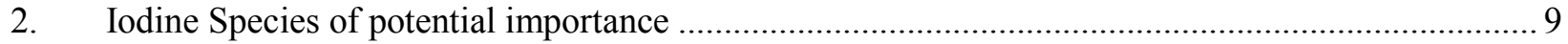

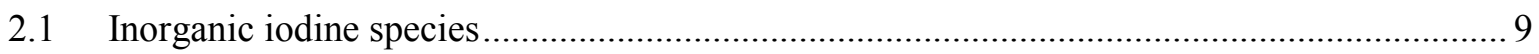

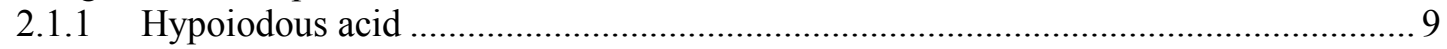

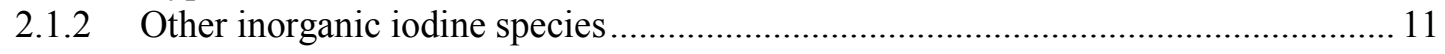

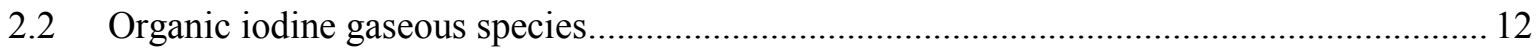

3. Thermodynamic Modeling of Potential Iodine Species ............................................................ 13

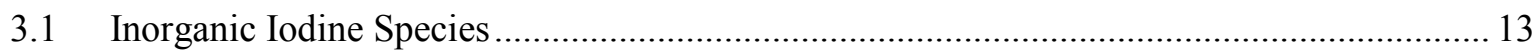

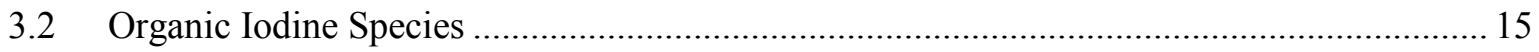

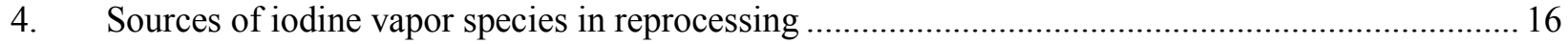

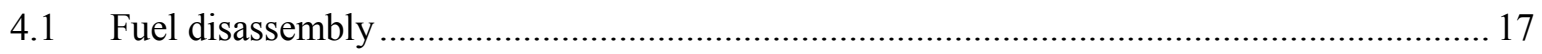

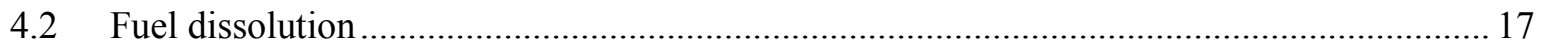

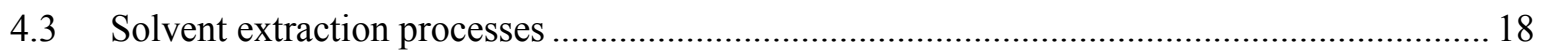

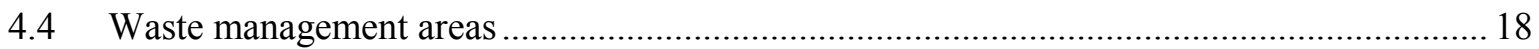

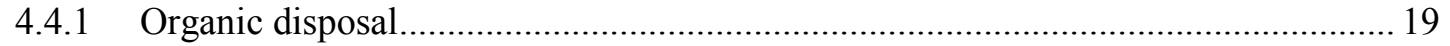

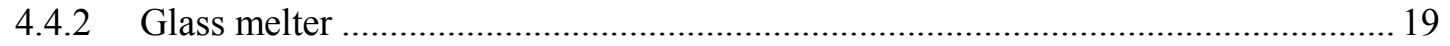

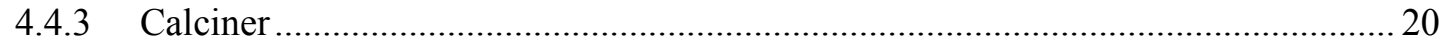

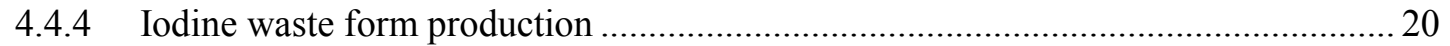

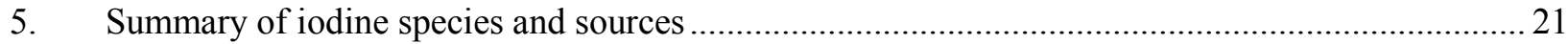

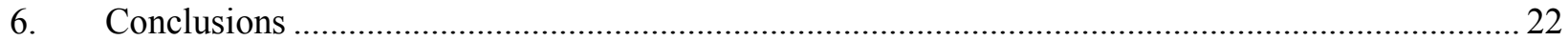

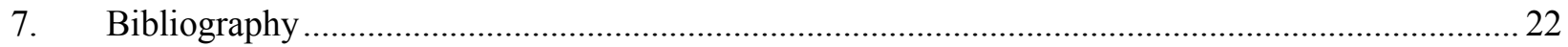




\section{FIGURES}

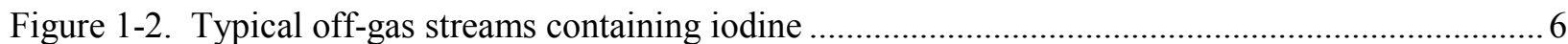

Figure 1-3: Contributions of each stream (\%) to overall plant iodine release (Base Case) ...................... 8

Figure 1-4: Contributions of each stream (\%) to overall plant iodine release (Case 3) ........................... 8

Figure 1-5: Contributions of each stream (\%) to overall plant iodine release (Case 6) ............................

Figure 2-1. An Eh-pH diagram for the aqueous iodine system $\left([\mathrm{I}]_{\text {total }}=1 \mu\right.$ molal $)$. The water stability region is bounded by short-dashed lines. 


\section{TABLES}

Table 1-1. Retention of gas phase iodine species by selective adsorbents (Evans and Jervis 1992) .......... 3

Table 1-2. Overall plant DF as a function of iodine splits and capture efficiency (numbers shown in red indicate a change from the preceding column) 7

Table 2-1: Equilibrium constants for the vaporization of HOI (Lin, 1981) ............................................. 10 
A Literature Survey to Identify Potentially Problematic Volatile lodine-Bearing Species Present in Off-gas Streams 


\section{ABBREVIATIONS AND ACRONYMS}

\begin{tabular}{|c|c|}
\hline $\operatorname{AgX}$ & Silver-loaded sorbent \\
\hline $\operatorname{AgZ}$ & Silver-loaded zeolite \\
\hline BWR & Boiling water reactor \\
\hline CANDU & Canada deuterium uranium (a Canadian reactor type) \\
\hline CCIM & Cold-crucible induction melter \\
\hline COG & Cell off-gas \\
\hline $\mathrm{DF}$ & Decontamination factor \\
\hline DOG & Dissolver off-gas \\
\hline EPA & Environmental Protection Agency \\
\hline HEPA & High efficiency particle arrestance or air (a highly effective particle filter) \\
\hline HLW & High-level waste \\
\hline HOG & Head-end off-gas \\
\hline HSC & Enthalpy $(\mathrm{H})$, entropy $(\mathrm{S})$ and heat capacity $(\mathrm{Cp})$ \\
\hline INL & Idaho National Laboratory \\
\hline KTB & Unnamed silver sorbent (Wilhelm and Schuttelkopf 1970) \\
\hline KTC & Unnamed silver sorbent (Wilhelm and Schuttelkopf 1970) \\
\hline KTD & Unnamed silver sorbent (Wilhelm and Schuttelkopf 1970) \\
\hline LCFM & Liquid-fed ceramic melter \\
\hline MOG & Melter off-gas \\
\hline ORNL & Oak Ridge National Laboratory \\
\hline PNNL & Pacific Northwest National Laboratory \\
\hline PUREX & Plutonium Uranium Redox Extraction \\
\hline SOG & Shear off-gas \\
\hline TBP & Tributylphosphate \\
\hline TEDA & Triethylenediamine \\
\hline UDS & Undissolved solids \\
\hline UNF & Used nuclear fuel \\
\hline VOG & Vessel off-gas \\
\hline WAK & Wiederaufarbeitungsanlage Karlsruhe \\
\hline WOG & Waste solidification off-gas \\
\hline
\end{tabular}




\section{A LITERATURE SURVEY TO IDENTIFY POTENTIALLY PROBLEMATIC VOLATILE IODINE-BEARING SPECIES PRESENT IN OFF-GAS STREAMS}

\section{INTRODUCTION}

Four radionuclides have been identified as being sufficiently volatile in reprocessing of nuclear fuel that their gaseous release needs to be controlled to meet U.S. regulatory requirements (Jubin et al. 2011, 2012). These radionuclides are ${ }^{3} \mathrm{H},{ }^{14} \mathrm{C},{ }^{85} \mathrm{Kr}$, and ${ }^{129} \mathrm{I}$. Of these, ${ }^{129} \mathrm{I}$ has the longest half-life and potential biological impact. Accordingly, control of the release of ${ }^{129} \mathrm{I}$ is most critical with respect to U.S. regulations for the release of radioactive material in stack emissions. Current U.S. Environmental Protection Agency regulation governing nuclear facilities (40 CFR 190) states that the total quantity of radioactive materials entering the general environment from the entire uranium fuel cycle, per gigawatt-year of electrical energy produced by the fuel cycle, must contain less than $5 \mathrm{mCi}$ of ${ }^{129} \mathrm{I}$.

Iodine, including the radioactive isotope ${ }^{129} \mathrm{I}$, is volatilized at multiple points during the reprocessing process, making its control a complex problem. Release points for significant quantities of ${ }^{129} \mathrm{I}$ include fuel dissolution, solvent extraction, and waste management processes. The off-gas streams from each of these processes, and other processes throughout the plant, have different characteristics and potentially result in the generation of a myriad of iodine-bearing species. Because iodine is fairly reactive, it can be distributed in different forms than the simple inorganic forms. A partial list of potential species includes: atomic iodine (I), elemental iodine $\left(\mathrm{I}_{2}\right)$, hydrogen iodide $(\mathrm{HI})$, hypoiodous acid $(\mathrm{HOI})$, iodine cyanide (ICN), methyl iodide $\left(\mathrm{CH}_{3} \mathrm{I}\right)$, higher alkyl iodides, up to dodecyl iodide $\left(\mathrm{C}_{12} \mathrm{H}_{25} \mathrm{I}\right)$, and aromatic iodides (e.g., $\left.\mathrm{C}_{6} \mathrm{H}_{5} \mathrm{I}\right)$ (Hebel and Cottone 1982). A number of these forms of iodine have historically proven to be problematic to identify and to effectively capture (Adams et al. 1967; Dillmann et al. 1990; Kabat 1974; Lee et al. 1991; McCracken 1985; Soo Hoo et al. 1975).

The study of inorganic iodide in off-gas systems has been almost exclusively limited to $\mathrm{I}_{2}$, and the focus of organic iodide studies has been $\mathrm{CH}_{3} \mathrm{I}$. In this document, we provide the results of an examination of publicly available literature that is relevant to the presence and sources of both inorganic and organic iodine-bearing species in reprocessing plants. We especially focus on those that have the potential to be poorly sequestered with traditional capture methodologies. In most cases, available literature on this topic is limited to laboratory studies, atmospheric studies, and thermodynamic predictions; these are discussed with the understanding that only some information from these studies can be extracted and applied to the generation and behavior of iodine in an operating reprocessing plant.

In the sections that follow, we provide a brief historical perspective on inorganic and organic iodides that have been observed in reprocessing facilities or associated laboratory studies and reported in the literature, a rationale for why the identification of these potentially difficult to capture iodides is important, an attempt to identify the potential sources and likely types of iodides that could be found in the off-gas streams, how these species might be identified, and, lastly, conclusions of this study and some suggestions for future work. The scope of this document is limited to the sources of iodine compounds in a reprocessing facility; a subsequent document is planned that will discuss the behavior of these species in off-gas treatment processes. The purpose of this document is to identify the sources and identities of potentially low-sorbing iodine-bearing species in a reprocessing plant and to illustrate the impact that potentially penetrating iodine species have on the decontamination factor (DF) of a reprocessing facility. This type of work promotes the design of a facility that can provide the highest quality of iodine abatement. 


\subsection{Early Indications of Low-sorbing lodine Forms}

The earliest reports of penetrating iodine forms occur in the 1960s (Adams 1966; Billard 1967;

Parker 1965). In these reports, the concept of a penetrating form of iodine arises from the observation of

${ }^{131}$ I activity that was not collected in the primary sorbent, but that was observed in downstream filters.

More complete characterization of these previously unidentified forms of iodine was performed by Browning et al. (1965). While their work focused on forms of iodine relevant to reactor accidents, many of their observations may be applicable to reprocessing. Browning et al. (1965) states that the various forms of radioiodine have been distinguished by their differing behavior in filters and on sorption materials, by their diffusion rates in the gas phase, by their tendencies to sorb on various materials in what was called a May Pack, and by other methods. Figure 1-1 shows the May Pack and experimental setup. May Packs utilize multiple types of sorbent traps in an effort to distinguish between different iodinebearing species. The most common species noted is the one, presumed to be $\mathrm{I}_{2}$, which deposits on metal surfaces such as silver or copper within the May Packs or in composite diffusion tubes. Almost always, at least initially, this is the most abundant form of iodine released in simulated reactor accidents, especially under non-reducing conditions.

The next most common vapor form of iodine reported by Browning et al. (1965) is a form that penetrates the metal gauze and particulate filters of a May Pack but deposits in the charcoal-loaded paper and is trapped by the deep granular charcoal bed. Atkins and Eggleton (1963) have observed this form in simulated reactor accidents and have identified one of its major constituents as methyl iodide $\left(\mathrm{CH}_{3} \mathrm{I}\right)$. This was also reported by Browning et al (1963). In this case it was reported that it passes through silverlined and rubber diffusion tubes but deposited upon an activated-carbon-lined diffusion tube. In a subsequent report, Browning et al. (1964) noted that the material was quite volatile at dry ice temperature, and it was adsorbed efficiently by activated charcoal under dry conditions, but not humid conditions. The failure of $\mathrm{CH}_{3} \mathrm{I}$ to adsorb to the metal gauze and particulate filters of a May Pack and to the silver and rubber diffusion tubes led to an early characterization of $\mathrm{CH}_{3} \mathrm{I}$ as one of the penetrating forms of iodine present in testing.

Browning and Ackley (1963) point to another unidentified vapor form of iodine characterized by the fact that it passed through a silver diffusion tube but was trapped on the surface of a rubber diffusion tube, has been observed in laboratory experiments, and appeared to be chemically unstable, especially at high temperature. Browning et al. (1965) also pointed out that there were other forms, such as HI and I, which may be important but had not yet been observed in simulated accidents. Investigations into iodine sequestration continued into the 1970s, and a primary focus included characterization of the effect of iodine concentration on the performance of carbon based sorbents (Ackley and Adams 1969; Craig et al. 1970; Milham and Jones 1969). The early work by Craig (1970) of South Africa, the Idaho Chemical works (Pence 1973), and others pointed to a decrease in removal efficiency as the iodine concentration decreased. However, this effect of iodine concentration was also explained by other authors (Jubin 1981) as the result of the existence of a more penetrating form of iodine such as HOI or the generation of such a compound.

Experiments performed by Dexter et al. (1977) revealed an unidentified form of penetrating iodine. This form penetrated through several inches of activated carbon. When similar experiments were conducted in a nitrogen atmosphere, the species were not observed; this provided evidence that oxygen was required for the formation of the species. Subsequent experiments were performed with flowing air and $\mathrm{a}-70^{\circ} \mathrm{C}$ cold trap, but the species was not captured.

In later studies on silver-exchanged sorbents, Pence et al. $(1972,1973)$ reported an apparent concentration effect on $\mathrm{AgX}$ that was more noticeable at lower gas velocities where the removal efficiency was higher. The effect may have been the result of a change in form of iodine to a more penetrating type, as was the case for carbon-bearing gas species. This occurred at $\mathrm{CH}_{3} \mathrm{I}$ concentrations in the range $10^{-5}$ to $10^{-4} \mu \mathrm{g} / \mathrm{m}^{3}$. 
Ackley and Combs (1973) indicated an apparent concentration effect on the removal efficiency of silverexchanged zeolites with low concentrations of silver on the zeolite. This effect became less distinct at high silver concentrations. A rather limited range of $\mathrm{CH}_{3} \mathrm{I}$ concentrations, 21 to $160 \mathrm{mg} / \mathrm{m}^{3}$, was examined in this study. Broothaerts et al. ( 1976) showed no concentration effect for $\mathrm{I}_{2}$ concentrations of 70 to $400 \mathrm{mg} / \mathrm{m}^{3}$ on $13 \mathrm{X}$ molecular sieves.

Wilhelm and Schuttelkopf (1970) introduced the use of several catalyst carriers impregnated with $\mathrm{AgNO}_{3}$ as materials to remove iodine from gas streams at elevated temperatures and from gas streams containing acid vapor. These experimental carriers (KTB, KTC, KTD) ${ }^{\text {a }}$ demonstrated a high removal efficiency $\left(>99.9944 \%\right.$ ) for $\mathrm{CH}_{3} \mathrm{I}$ on 1.6-mm pellets with sorbent silver concentrations of $\leq 78 \mathrm{~g} / \mathrm{kg}, \mathrm{CH}_{3}{ }^{131} \mathrm{I}$ loadings of 1 to $2 \mathrm{mg} / \mathrm{g}\left(\right.$ as $\mathrm{CH}_{3}{ }^{131} \mathrm{I}$ ) at $30^{\circ} \mathrm{C}$, and a relative humidity of $70 \%$; however, at $100 \%$ relative humidity, the removal efficiency dropped to $27 \%$. The removal efficiency varied directly with the bed depth and inversely with relative humidity and loading. It was also noted by Wilhelm and Schuttelkopf (1970) that an iodine compound more penetrating than $\mathrm{CH}_{3} \mathrm{I}$ was present and that the $\mathrm{KTC}$ material had a very low efficiency for its removal

The number of potential iodine sorbents has expanded over the decades. Evans and Jervis (1992) conducted an experiment designed to examine how different sorbents capture different forms of iodine. Various forms of iodine were made by labeling commercially purchased or laboratory-made solutions with ${ }^{131} \mathrm{I}$. The results from this test showed that different sorbents evaluated during the study had very different responses for the different forms of iodine.

Table 1-1. Retention of gas phase iodine species by selective adsorbents (Evans and Jervis 1992)

\begin{tabular}{|r|c|c|c|c|}
\hline \multirow{2}{*}{ Solution } & \multicolumn{4}{|c|}{ Amount Retained, \% } \\
\cline { 2 - 5 } & Teflon ${ }^{\circledR}$ fiber & $\mathrm{CdI}_{2}$ & Iodophenol & TEDA/Charcoal \\
\hline $\mathrm{I}_{2}$ & 7 & 92 & $<0.1$ & $<0.1$ \\
\hline $\mathrm{HOI}$ & $<1$ & 4 & 95 & $<1$ \\
\hline $\mathrm{CH}_{3} \mathrm{I}$ & $<0.1$ & $<0.1$ & 0.2 & 99.7 \\
\hline $\mathrm{C}_{2} \mathrm{H}_{5} \mathrm{I}$ & $<0.1$ & $<0.1$ & 1 & 31 \\
\hline $\mathrm{C}_{4} \mathrm{H}_{9} \mathrm{I}$ & $<0.1$ & 0.3 & 69 & 0 \\
\hline $\mathrm{CHI}_{3}$ & 3 & 89 & 8 & \\
\hline
\end{tabular}

$\mathrm{CdI}_{2}: \mathrm{CdI}_{2}$ on Chromosorb-P

Iodophenol: $\mathrm{IC}_{6} \mathrm{H}_{4} \mathrm{OH}$ on activated alumina

TEDA/charcoal: triethylenediamine (TEDA)-impregnated charcoal

\subsection{Importance of Understanding Low-sorbing lodine Species}

Much of the past work on iodine removal has been primarily focused on the dissolver off-gas (DOG) stream. Addressing only this source of iodine does not provide the estimated emissions control efficiency of $99.9 \%$ or higher over the entire plant that is needed to meet U.S. regulatory requirements. Operating experience and tests with actual nuclear fuel show that iodine evolution from the dissolver solution into the DOG ranges between 95 and 99\% (Sakurai et al. 1997; Sakurai et al. 1989; Sakurai et al. 1995;

\footnotetext{
${ }^{a}$ These were unnamed experimental substrates from the Bayer Factory (Wilhelm and Schuttelkopf 1970).
} 
Sakurai et al. 1996; Sakurai et al. 1992). Iodine evolution from the dissolver solution can be improved to $>95 \%$ with $\mathrm{NO}_{2}$ sparging and addition of $\mathrm{KIO}_{3}$ or other iodates to the dissolver (Sakurai et al. 1996;

Sakurai et al. 1993). Several studies have shown that much of the residual iodine in the dissolver solution is in the form of colloidal (AgI and $\mathrm{PdI}_{2}$ ) or organic iodides (Sakurai et al. 1997; Sakurai et al. 1989; Sakurai et al. 1992). Iodine present in these compounds may volatilize and disperse into other reprocessing facility off-gas streams, resulting in $1-5 \%$ of iodine requiring capture from streams other than that of the DOG.

To understand the importance of capturing low-sorbing forms of iodine, a calculation of the overall plant DF was carried out by estimating the iodine splits, speciation, and individual DF values for each off-gas stream within the used nuclear fuel (UNF) reprocessing plant. In this calculation carried out in an Excel ${ }^{\circledR}$ spreadsheet, assumptions regarding the presence of penetrating forms (such as $\mathrm{CH}_{3} \mathrm{I}, \mathrm{HOI}$, etc.) at each step were made based on observations reported in the literature and summarized by Jubin et al (2013). The Excel spreadsheet was used to track both elemental and penetrating forms of iodine separately and allowed changes in the speciation of iodine at each processing step. Assumptions regarding the DFs for elemental and penetrating iodine-bearing species at each off-gas system were also made based on data reported in literature. To look at the effect on the overall facility DF, cases were considered in which the DF values for the penetrating species of iodine were reduced by a factor of two to 10 from the reported or anticipated DF value for elemental iodine. (As a point of reference, a base case was calculated in which no reduction in DF was taken for the penetrating forms. The contribution of each stream to overall plant iodine release is shown in Figure 1-3.)

For the initial analysis (Case 1), an "optimistic" DF reduction factor of 2 was used for the penetrating forms. The desired target overall DF was assumed to be between 1000 and 3000 to meet regulations with a reasonable design margin (Jubin et al. 2014). Figure 1-1 shows the expected iodine pathways within a reprocessing facility. For ease of calculation, it was assumed that a total of $100 \mathrm{~g}$ of iodine entered with the UNF. Of this inventory, $0.01 \%$ was assumed to volatilize when the fuel is disassembled and chopped from which it enters the head-end cell gas stream hereafter referred to as the shear off-gas (SOG) (Stream A; Figure 1-1). The SOG stream is assumed to only undergo particulate removal (i.e., no iodine abatement or an iodine DF of 1). The iodine in this stream was assumed to be $\mathrm{I}_{2}$. Of the remaining amount of iodine, $96 \%$ was assumed to volatilize in the fuel dissolver (Stream B; Figure 1-1). Iodine DF values for the DOG stream are assumed to be 4000 for $\mathrm{I}_{2}$ and 2000 for penetrating forms. It was assumed that $5 \%$ of the iodine that was volatized in the dissolver was converted to a penetrating species of iodine. Of the iodine that enters the DOG abatement system, only $0.025 \%$ was not retained and was subject to stack release. The remaining amount of iodine from the fuel was tied up as insoluble inorganics [e.g., $\mathrm{PdI}_{2}$ and AgI (Sakurai et al. 1997; Sakurai et al. 1989; Sakurai et al. 1992)], insoluble organic solids, or organics that were dissolved in the dissolver solution. Of the iodine that is volatilized from the dissolver, $0.07 \%$ was allowed to escape to the cell into the cell off-gas (COG) system (Stream C; Figure 1-1). This stream has the same composition as the DOG and represents gas leakage from the dissolver (e.g., through the dissolver seal). Iodine DF values for the COG stream were assumed to be 1 for elemental iodine and 1 for penetrating forms (i.e., no iodine abatement).

After the dissolver, it is assumed that $\sim 50 \%$ of the iodine remaining in the dissolver solution is released into the vessel off-gas (VOG) system (Stream D; Figure 1-1). The flow of the VOG stream may be on the order of 10 times greater than that of the DOG stream. The iodine concentration in this stream may be four to five orders of magnitude lower than the concentration in the DOG because of the higher gas flow and the smaller, but not insignificant, quantity of iodine present. A significant fraction of the iodine in the VOG is assumed to be organic iodides. For this analysis, it is assumed that $50 \%$ is organic or penetrating iodine-bearing gas species. Here an elemental iodine DF of 1000 and a DF of 500 for penetrating forms, including the all organic iodides, are assumed. 
The remaining $50 \%$ of residual iodine in the dissolver solution either entered into the solvent extraction system or remained as insoluble species in the aqueous phase. The organic iodides in the organic solvent may volatilize into the VOG or can remain with the organic that enters the waste solidification processes (Boukis and Henrich 1991a, b). Any iodine that is evolved from the solvent extraction or solvent treatment systems enters into the VOG and is accounted for there. The waste organic is assumed to be pyrolyzed or incinerated in the liquid waste solidification operations. The aqueous waste from separations and other operations will also contain some iodine and will also be solidified in the liquid waste solidification operations. The liquid waste solidification systems are assumed to be hightemperature operations (i.e., incineration or pyrolization for waste organics and a glass melter for the other insolubles that follow the aqueous stream), and the iodine was assumed to be converted primarily to $\mathrm{I}_{2}$. (Note that all off-gas streams from the waste solidification operations are combined into this single stream for this analysis.) A limited amount of information was found on the release of iodine during waste solidification operations. The quantities of release were found to be process specific. The range of release was estimated to be between 0.1 and $1 \%$ of the iodine inventory in the plant. For the initial analysis, it was assumed that $20 \%$ of the iodine reaching the waste solidification processes was volatized. This resulted in $\sim 1 \%$ of the iodine in the original fuel being released into the waste off-gas stream. Of this, $10 \%$ was assumed to be a penetrating species such as a high molecular weight organic iodide that resulted from pyrolysis of the organics still in the feeds to these processes. Iodine DF values for the waste solidification off-gas (WOG) stream (Stream E; Figure 1-1) were assumed to be 1000 for elemental iodine and 500 for penetrating forms.

The above set of assumptions and DF values yields an overall facility DF of 906 (Case 1 of Table 1-2). Of the iodine reaching the stack, $90 \%$ is from elemental iodine and $10 \%$ is from penetrating forms. Of the elemental iodine reaching the stack, $60 \%$ is from the head-end cell, visualized in Figure 1-3. The Case 1 overall DF can be compared to the base case in which it was assumed that there was no change in iodine DF for the more penetrating iodine species or that penetrating forms were not present. The overall DF for the base case was calculated to be $\sim 935$. The difference between these two cases is minimal. If a less optimistic DF (assume a DF reduction factor of 5 rather than 2) is used for the penetrating iodine species, the overall DF drops to $\sim 825$ (Case 2).

Increasing the DOG DF value to 10,000 and selecting the optimistic DF reduction factor of 2 for penetrating forms changes the overall plant DF to 1040 (Case 3; Table 1-2), which is just barely over the low end of the target DF range of $1000-3000$ for the facility. Selecting the less optimistic reduction factor of 5 reduces the overall DF to 960 (Case 4; Table 1-2). Approximately 16\% of the iodine reaching the stack is the penetrating forms. With these relatively high iodine DFs, a significant fraction of the iodine reaching the stack is from the head-end cell off-gas, which is untreated (Figure 1-4).

Iodine DFs for the VOG stream may be more on the order of 100 rather than the 1000 assumed above. In this case, assuming a DF reduction factor of 5 for penetrating iodine species, the overall plant DF is only $\sim 400$, and over 50\% of the iodine reaching the stack is from penetrating forms (Case 5; Table 1-2).

Hrma (2010) determined that the retention of iodine in a dynamic waste solidification system (continuous feed) was about $20 \%$. Most of the iodine was found to be volatilized as the melter feed was dried, calcined, and melted as the liquid feed transitioned to the glass. If additional iodine is released into the WOG, the overall DF is decreased to 340 and just slightly under $50 \%$ of the iodine reaching the stack is from penetrating forms (Case 6; Table 1-2). The contributions of each stream to the overall plant iodine release are shown in Figure 1-5.

Figure 1-2 illustrates the primary iodine pathways and Table 1-2 shows how the individual streams, iodine splits and associated capture efficiencies impact the overall plant DF (Note: the off-gas from the solvent treatment systems is included in the VOG). In Table 1-2, changes from one column to the next are highlighted in red. 
These analyses lead to several key observations. First, in spite of high DF values for the DOG, the losses to the head-end cell appear to control overall plant DF since this is assumed to be an untreated stream. Second, the ability to trap iodine from the VOG may be a limiting factor to the overall plant DF as it may be harder to achieve high iodine DFs in this high-volume, low-concentration stream, and this is also the stream where penetrating iodine species are most likely. Third, the contributions from penetrating forms of iodine to the plant DF are largely unknown and highly dependent on the magnitude of their presence; the overall plant DF depends strongly on the possible DF that can be achieved at each off-gas stream. Closure of this knowledge gap would allow for better analysis of the contribution that penetrating forms of iodine may have on achieving the desired overall plant target DF. If their impact is determined to be limiting, development of new capture technologies may be required.

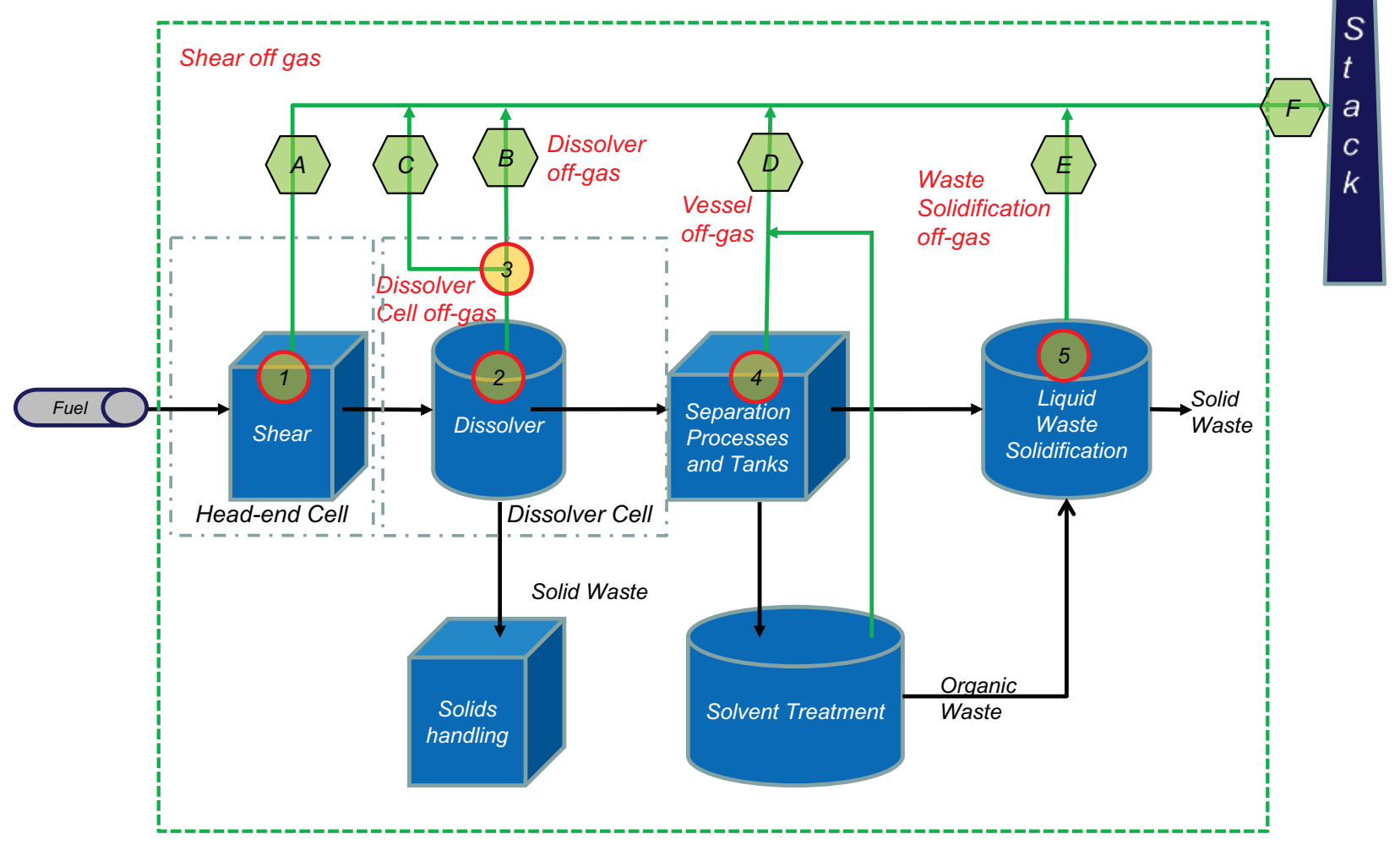

Figure 1-1. Typical off-gas streams containing iodine 
A Literature Survey to Identify Potentially Problematic Volatile lodine-Bearing Species Present in Off-gas Streams

Table 1-2. Overall plant DF as a function of iodine splits and capture efficiency (numbers shown in red indicate a change from the preceding column)

\begin{tabular}{|c|c|c|c|c|c|c|c|}
\hline lodine Sources and Splits & $\begin{array}{l}\text { Base } \\
\text { Case }\end{array}$ & Case 1 & Case 2 & Case 3 & Case 4 & Case 5 & Case 6 \\
\hline \multicolumn{8}{|l|}{$\begin{array}{l}\text { Assumed lodine Partition - } \\
\text { Percent of iodine split to } \\
\text { specified process I } \\
\text { operation (\%) }\end{array}$} \\
\hline $\begin{array}{l}\text { lodine released to head- } \\
\text { end cell or Shear off-gas } \\
\text { (SOG) }(\%)\end{array}$ & 0.01 & 0.01 & 0.01 & 0.01 & 0.01 & 0.01 & 0.01 \\
\hline $\begin{array}{l}\text { lodine entering the } \\
\text { dissolver and released to } \\
\text { the DOG }(\%)\end{array}$ & 96 & 96 & 96 & 96 & 96 & 96 & 96 \\
\hline $\begin{array}{l}\text { DOG that escapes to the } \\
\text { COG }(\%)\end{array}$ & 0.07 & 0.07 & 0.07 & 0.07 & 0.07 & 0.07 & 0.07 \\
\hline $\begin{array}{l}\text { lodine released to the VOG } \\
\text { from aqueous separations } \\
\text { tanks / processes }(\%)\end{array}$ & 50 & 50 & 50 & 50 & 50 & 50 & 50 \\
\hline $\begin{array}{l}\text { lodine released to the } \\
\text { WOG }(\%)\end{array}$ & 20 & 20 & 20 & 20 & 20 & 20 & 80 \\
\hline \multicolumn{8}{|l|}{$\begin{array}{l}\text { lodine DF by off-gas stream } \\
\text { and species }\end{array}$} \\
\hline $\begin{array}{l}\text { Head-end cell off-gas }\left(\mathrm{I}_{2}\right. \\
\text { and penetrating) }\end{array}$ & 1 & 1 & 1 & 1 & 1 & 1 & 1 \\
\hline DOG $\left(I_{2}\right)$ & 4000 & 4000 & 4000 & 10,000 & 10,000 & 10,000 & 10,000 \\
\hline DOG (penetrating) & 4000 & 2000 & 800 & 5000 & 2000 & 2000 & 2000 \\
\hline Dissolver cell off-gas $\left(I_{2}\right)$ & 1 & 1 & 1 & 1 & 1 & 1 & 1 \\
\hline $\operatorname{VOG}\left(I_{2}\right)$ & 1000 & 1000 & 1000 & 1000 & 1000 & 100 & 100 \\
\hline VOG (penetrating) & 1000 & 500 & 200 & 500 & 200 & 20 & 20 \\
\hline $\begin{array}{l}\text { Waste solidification off-gas } \\
\left(\mathrm{I}_{2}\right)\end{array}$ & 1000 & 1000 & 1000 & 1000 & 1000 & 100 & 100 \\
\hline $\begin{array}{l}\text { Waste solidification off-gas } \\
\text { (penetrating) }\end{array}$ & 1000 & 500 & 200 & 500 & 200 & 20 & 20 \\
\hline Overall Plant DF & 935 & 906 & 825 & 1040 & 960 & 420 & 340 \\
\hline
\end{tabular}


A Literature Survey to Identify Potentially Problematic Volatile lodine-Bearing Species Present in Off-gas Streams

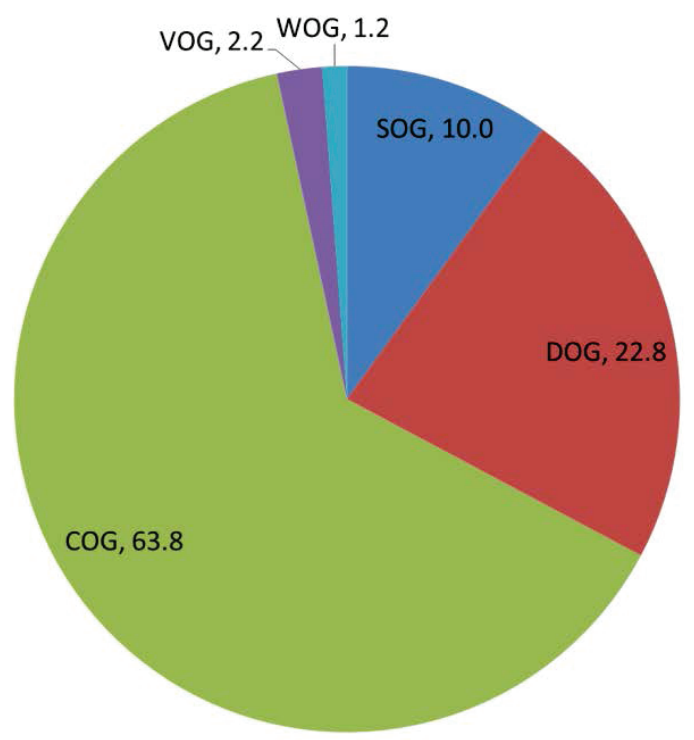

Figure 1-2: Contributions of each stream (\%) to overall plant iodine release (Base Case)

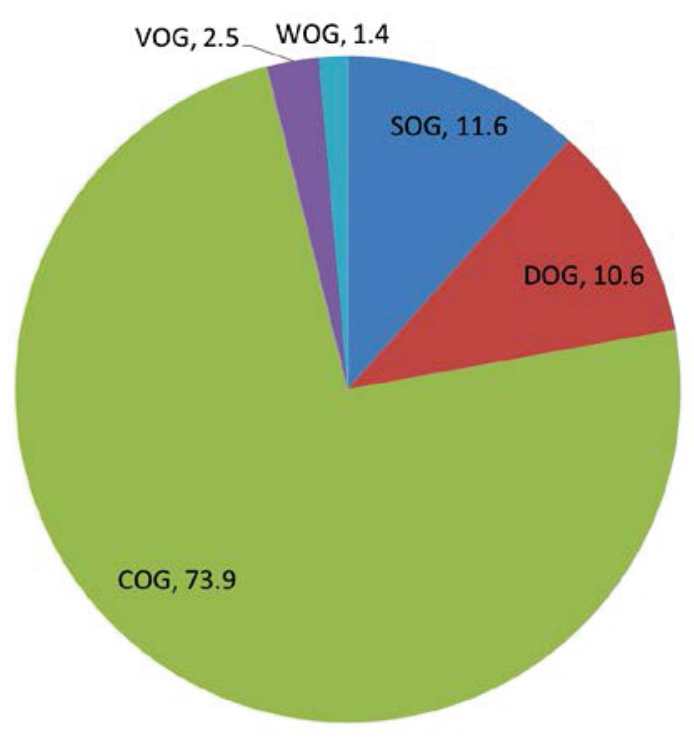

Figure 1-3: Contributions of each stream (\%) to overall plant iodine release (Case 3) 


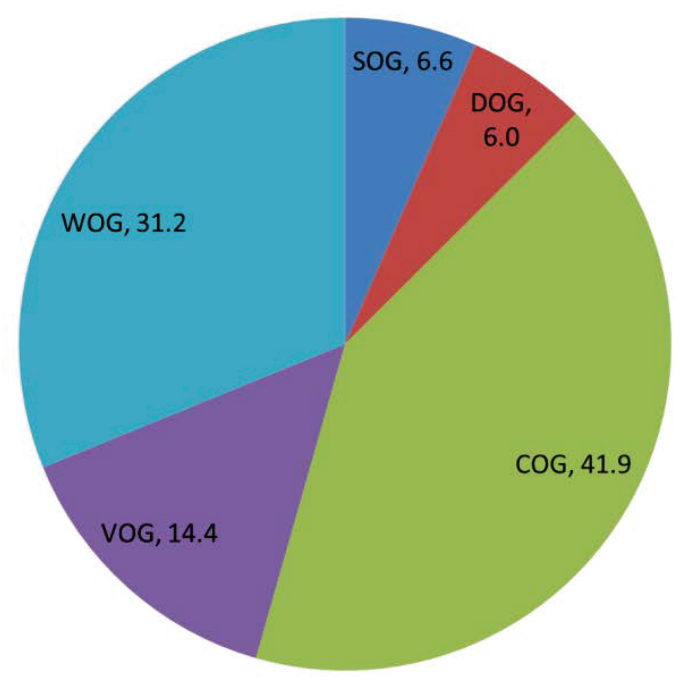

Figure 1-4: Contributions of each stream (\%) to overall plant iodine release (Case 6)

\section{2. lodine Species of potential importance}

In addition to $\mathrm{I}_{2}$ and $\mathrm{CH}_{3} \mathrm{I}$, several iodine-bearing species were identified as likely to be present in multiple off-gas streams. These are discussed here, with special emphasis on HOI and long-chain organic iodides. These are two types of iodine-bearing species that are often overlooked in studies of iodine capture from off-gas streams.

\subsection{Inorganic iodine species}

\subsubsection{Hypoiodous acid}

HOI is a volatile inorganic iodine species (Baker et al. 2001; Castleman et al. 1965; Harrell et al. 1988; Keller et al. 1970b). Its behavior in containment buildings of nuclear power plants has been investigated (Routamo 1996; Wren et al. 1986; Keller et al. 1970b), but its behavior in a nuclear reprocessing facility is largely unknown. In most available literature, the presence of HOI is often only assumed or inferred, rather than confirmed through direct analysis (Borisov 2004; Kabat 1983). The existence of airborne HOI in a steam air atmosphere was first postulated in 1968 by Cartan et al. (1968) of Idaho Nuclear Corporation. Numerous investigators (Browning et al. 1964; Chamberlain et al. 1963; Nakhutin et al. 1969) have observed an iodine compound (neither elemental nor organic) in a humid atmosphere. This species is also found in the atmosphere (Chameides and Davis 1980; Hou et al. 2009; Jabbar et al. 2013).

This literature survey did not find reference to the presence of HOI in the effluent of an operational reprocessing facility. As HOI is not well adsorbed by many types of media and is not easily differentiated from other iodine forms, it is unclear whether HOI does not exist in the off-gas streams of a reprocessing facility or its potential presence has not been investigated. There are reports of HOI present in the gaseous effluent of both boiling water reactors (BWRs) and Canada deuterium uranium (CANDU) reactors, and it has also been observed in nuclear accidents (Kabat 1982; Marrero 1977). Due to its observation in these nuclear processes and its possible formation in off-gas streams, HOI merits further investigation as to whether it is present and evaluation of its potential impact on plant DF.

Formation of HOI can occur through hydrolysis of elemental iodine (Reaction 2-1) but Eigen and Kustin (1962) states that the equilibrium constant for this reaction is very small $\left(K_{h y d r}=4.3 \times 10^{-12}\right)$ in the 
absence of metal reactants [e.g., iron (Reaction 2-2) or mercury (Reaction 2-3)] or a radiation field (Kulyukhin 2011). In contrast, Keller (1971) asserts that HOI may be easily formed through the sparging of a heated aqueous solution containing solely elemental iodide. We conclude that the formation of HOI is likely promoted by the myriad of fission products present in aqueous reprocessing, and it is then volatilized and observed throughout off-gas streams, especially those of the DOG and VOG. The heat of formation of HOI has been found to be roughly $-70 \mathrm{~kJ} / \mathrm{mol}$ (Šulková et al. 2013).

$\mathrm{H}_{2} \mathrm{O}+\mathrm{I}_{2} \leftrightarrow \mathrm{HI}+\mathrm{HOI}$

$\mathrm{Fe}+2 \mathrm{I}_{2}(g)+\mathrm{H}_{2} \mathrm{O}(g) \leftrightarrow \mathrm{FeI}_{2}+\mathrm{HIO}(g)+\mathrm{HI}(g)$

$2 \mathrm{HgO}+2 \mathrm{I}_{2}+\mathrm{H}_{2} \mathrm{O} \leftrightarrow \mathrm{HIO}+\mathrm{HgO}+\mathrm{HgI}_{2}$

Experiments by Keller et al. (1970b) showed that the optimum conditions for the formation of HOI in an aqueous system are an iodine concentration in liquid of approximately $10^{-6} \mathrm{molal}$, a $\mathrm{pH}$ of 10 , and a temperature of $90^{\circ} \mathrm{C}$. Morgan and Holland (1980) suggest that HOI is present in dissolver solutions as the concentration of iodine approaches $1 \mu$ molal.

Lin (1981) states that HOI is also a more dominant species in the gas phase as well as at low concentrations. Lin also provides a table of equilibrium constants for the vaporization of $\mathrm{HOI}\left(K_{\text {vap }}\right)$ as a function of temperature and states that such a reaction is kinetically rapid. At the temperature of the dissolver (approximately $100^{\circ} \mathrm{C}$ ), the equilibrium constant for vaporization is 30 times higher than at $25^{\circ} \mathrm{C}$.

Kabat (1981) ran experiments to determine the iodine speciation during a reactor accident. He found that virtually all the iodine was present as $\mathrm{HOI}$ at temperatures $<250^{\circ} \mathrm{C}$. Additionally, Kabat (1974) presented the results of an extensive study of the relations and kinetics for the production of HOI.

Table 2-1: Equilibrium constants for the vaporization of HOI (Lin, 1981)

\begin{tabular}{|c|c|}
\hline Temperature $\left({ }^{\circ} \mathbf{C}\right)$ & $\boldsymbol{K}_{\text {vap }}$ \\
\hline 20 & $4.04 \times 10^{-3}$ \\
\hline 25 & $5.34 \times 10^{-3}$ \\
\hline 50 & 0.086 \\
\hline 100 & 0.126 \\
\hline 150 & 0.5 \\
\hline 200 & 1.4 \\
\hline 250 & 3.05 \\
\hline 300 & 5.56 \\
\hline
\end{tabular}

The lifetime of HOI in the vapor state is unknown but estimated to be on the order of days (Keller et al. 1970a). Hypoiodous acid can deprotonate (Reaction $2-4, K_{a}=2.3 \times 10^{-11}$ ) or can disproportionate to 
either relatively non-volatile iodates (Reaction 2-5) or elemental iodine (Reaction 2-6). These reactions are expected to be slow.

$\mathrm{HIO} \leftrightarrow \mathrm{H}^{+}+\mathrm{IO}^{-}$

$3 \mathrm{HOI} \leftrightarrow \mathrm{HIO}_{3}^{-}+2 \mathrm{HI}$

$5 \mathrm{HIO} \leftrightarrow 2 \mathrm{I}_{2}+\mathrm{HIO}_{3}+2 \mathrm{H}_{2} \mathrm{O}$

Although HOI is considered a penetrating species of iodine due to its failure to adsorb to traditional iodine capture media, there are multiple types of adsorbents reported to sequester HOI. These include various forms of impregnated charcoal (Borisov 2004), copper zeolite (Keller 1971), phenol-impregnated alumina (Keller 1971), and natural organic matter (Ikari et al. 2015).

There are limited analytical methods available for detection or quantification of HOI. The most distinctive and direct analysis method for HOI is to perform an iodination reaction with phenol. Hypoiodous acid was demonstrated to be the sole iodine species that forms iodinated phenol (Berliner 1951). It is likely that bubbling of an iodine-containing gas stream through a solution containing phenol would provide quantification of the amount of HOI present in the gas stream (Lin 1981). Other studies have demonstrated indirect confirmation of HOI through gas chromatography (Borisov 2004) and various forms of spectroscopy (Barnes et al. 1992; Rahn 1991).

It should also be noted that, if the conversion of complex iodine-bearing compounds to $\mathrm{I}_{2}$ is ineffective or some of the $\mathrm{I}_{2}$ is converted to $\mathrm{HOI}$ through reaction between $\mathrm{I}_{2}$ and $\mathrm{H}_{2} \mathrm{O}$, then iodine removal systems located in the tail-end waste processing processes of the facility need to be designed to handle these penetrating forms of iodine (Kulyukhin et al. 2011; Saiz-Lopez et al. 2012; Wren et al. 1987). These complex iodides may or may not be similar to those generated elsewhere in the facility.

\subsubsection{Other inorganic iodine species}

The inorganic speciation of iodine in aqueous systems as a function of possible Eh and $\mathrm{pH}$ values present in the aqueous solutions of a reprocessing facility is relatively simple. A Pourbaix Diagram (Eh vs $\mathrm{pH}$ ) of the aqueous iodine system is shown in Figure 2-1; absent are the species $\mathrm{HIO}_{4}{ }^{-}$and $\mathrm{HIO}_{5}{ }^{-}$, as these were not present in the thermodynamic properties data base. At high $[\mathrm{I}]_{\text {total, }}$, the species triiodide $\left(\mathrm{I}_{3}{ }^{-}\right)$ becomes significant and forms a region of stability between $\mathrm{I}_{2}$ and $\mathrm{I}^{-}$. This occurs in the mmolal range of $[\mathrm{I}]_{\text {total }}$ at which concentration the solubility of $\mathrm{I}_{2}$ is reached, ( $\sim 2$ mmolal). Iodates and $\mathrm{I}_{3}{ }^{-}$are not highly volatile, and should not contribute significantly to total iodine in off-gas streams.

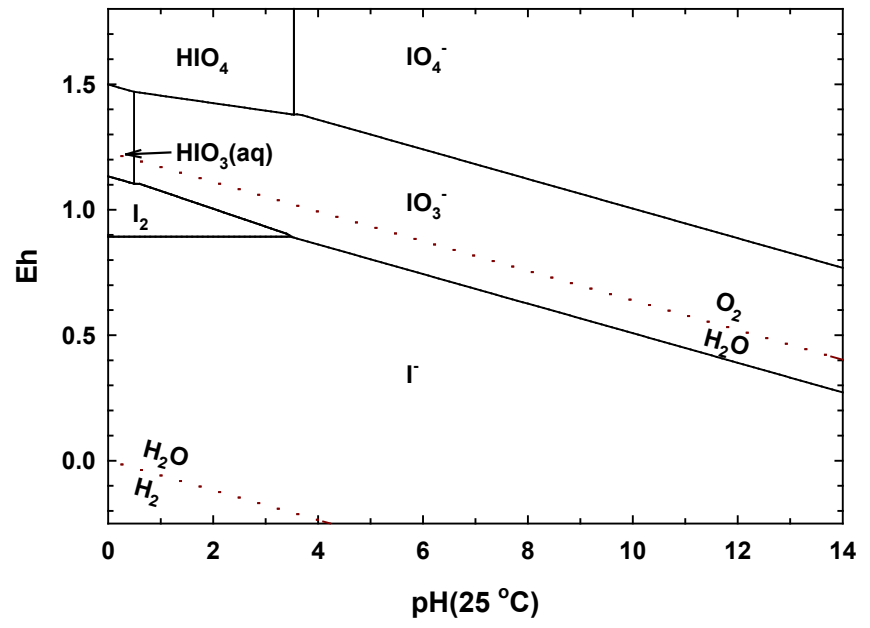

Figure 2-1. An Eh-pH diagram for the aqueous iodine system $\left([\mathrm{I}]_{\text {total }}=1 \mu\right.$ molal $)$. The water stability region is bounded by short-dashed lines 
While $\mathrm{IO}_{3}{ }^{-}$is likely the only non-volatile iodine species dissolved in aqueous aerosols, other dissolved species are linked chemically to other volatile halides, e.g.

$I^{-}+\mathrm{HOCl} \leftrightarrow \operatorname{ICl}(g)+\mathrm{H}_{2} \mathrm{O}$

Most of these species have been identified in the atmospheric (Baker et al. 2001; Filistovic and Nedveckaite 1998; Hodotsuka et al. 2008; Moore and Groszko 1999; Moore and Tokarczyk 1992; Saiz-Lopez et al. 2012; Sturges and Barrie 1988; Yoshida and Muramatsu 1995; Zhang and Hou 2013) or reactor accident literature (Browning 1963; Browning et al. 1963; Browning et al. 1965; Browning et al. 1964; Choi et al. 2001; Paquette 1989; Parsley 1971; Routamo 1996; Wren et al. 1986). Despite the differences between reprocessing off-gas streams and the atmosphere such as temperature and overall composition, the concentrations of iodine species in the atmosphere are similar to or slightly less than those expected in a reprocessing facility (Campos et al. 1996) and the iodine-bearing species are similar to those expected in a reprocessing facility (Baker et al. 2001; Campos et al. 1996; Filistovic and Nedveckaite 1998; Hodotsuka et al. 2008; Moore and Groszko 1999; Moore and Tokarczyk 1992; SaizLopez et al. 2012; Sturges and Barrie 1988; Yoshida and Muramatsu 1995; Zhang and Hou 2013).

Burger and Scheele (2004) discuss the expected iodine-bearing species in the off-gas from a glass melter. They conclude that the dominant inorganic species is iodine monochloride (ICl) because of the overwhelming amount of chloride (from impurities in commercially available nitric acid) that is expected in the off-gas stream. They conclude that HI should not exist in the melter off-gas (MOG) because of the high temperatures although it may exist in lower temperature processes.

\subsection{Organic iodine gaseous species}

Some of the major iodine-bearing species found in the soils of the Savannah River Site were found to be organic iodides (Chang et al. 2014; Emerson et al. 2014; Schwehr et al. 2014; Schwehr and Santschi 2003; Schwehr et al. 2005; Schwehr et al. 2009). Wershofen and Aumann (1989) found that a significant fraction of the radioiodine released from the Karlsruhe Reprocessing Plant was organic. Mixed halide species, e.g., ICl, $\mathrm{CH}_{3} \mathrm{CHICl}$, etc., have also been found in off-gas streams (Moore and Tokarczyk 1992; Sturges and Barrie 1988). Mixed organohalide species should be expected in reprocessing off-gas streams because of the presence of $\mathrm{Cl}$ in the solutions at concentrations that far exceed those of iodine (Jubin et al. 2013).

Reed and coworkers (2002) determined that organic iodides and $\mathrm{I}_{2}$ were present in the spent tributylphosphate (TBP) kerosene solvent from the reprocessing facility at Sellafield. Quantitative measurements were not possible since the analytical method that was used yielded confounding results that did not allow the separation of molecular iodine from organic iodides with subsequent speciation. They were able to obtain the iodine spectra from a spent solvent sample from nuclear fuel reprocessing that contained iodine at $40 \mathrm{mg} / \mathrm{L}$ and found iodine in oxidation states from I(II) to I(VII).

Volatile organic iodides can be formed in otherwise pure $\mathrm{HNO}_{3}$ (Nakamura et al. 1973; Tachikawa 1973), whereas they do not form in other acids such as $\mathrm{HCl}, \mathrm{HClO}_{4}$, and $\mathrm{H}_{2} \mathrm{SO}_{4}$ (Nakamura et al. 1973).

Nakamura and coworkers found that the volatile organic iodides $\mathrm{CH}_{3} \mathrm{I}, \mathrm{C}_{2} \mathrm{H}_{3} \mathrm{I}, \mathrm{C}_{2} \mathrm{H}_{5} \mathrm{I}, n-\mathrm{C}_{3} \mathrm{H}_{7} \mathrm{I}$, and $n-\mathrm{C}_{4} \mathrm{H}_{9} \mathrm{I}$ were formed from very dilute ${ }^{131} \mathrm{I}_{2}$-bearing solutions. This indicates that the nitric acid contained the organics when purchased, similar to what is expected in a reprocessing facility (Burch et al. 1977; Jubin et al. 2013). This has bearing on the expected speciation of organic iodides found in the dissolver.

Henrich et al. (1981) report that organic iodides in the dissolver solution can result in volatilization of iodine species into the VOG. For the VOG, the iodine filters showed reduced DFs after about $40 \mathrm{~d}$. This was attributed to the presence of organics in the VOG. From the gas chromatographic analyses, they found iodododecane $\left(\mathrm{C}_{12} \mathrm{H}_{25} \mathrm{I}\right)$ as the dominant organic iodide. The observation that $\mathrm{C}_{12} \mathrm{H}_{25} \mathrm{I}$ could be the 
primary organic iodine species present in the VOG is notable. It is likely that $\mathrm{C}_{12} \mathrm{H}_{26}\left(\right.$ or $\mathrm{C}_{12} \mathrm{H}_{26}$ radicals formed from radiolysis) present in large amounts as the diluent could react with substantial amounts of available iodine to form $\mathrm{C}_{12} \mathrm{H}_{25} \mathrm{I}$.

Wilhelm et al. (1977) also found that a fraction of the residual iodine contained in the fuel solution was found in the VOG. A number of organic radicals are likely to be present in the solvent extraction solutions as a result of radiolytic degradation. These, in turn, could have reacted with the iodine. Thus, they expected a high fraction of organic iodide in the vessel off-gas.

Herrmann et al. (1988) reported that the conditions for iodine capture from the vessel off-gas were less favorable than in the dissolver off-gas. The reasons provided were:

- The ${ }^{129}$ I concentrations in the VOG were lower by the factor of $10^{5}$.

- The VOG stream flow rate was 5 to $20 \times$ higher.

- The vessel off-gas contained organic compounds that may have poisoned the iodine sorbent material (Ag-loaded AC 6120 in this case), for example, dodecane and organic radiolytic products.

Tests were initiated in 1987 with a side stream of the Wiederaufarbeitungsanlage Karlsruhe (WAK) VOG system. Ten percent of the VOG comprised this side stream. During the first six months, the DF was $>100$ on a Ag-loaded (12 mass\% Ag) AC6120 sorption bed. When the DF decreased to 20, the bed was regenerated. Gas chromatographic analyses of traps installed in the system indicated that the predominant iodine-containing organic compound in the VOG was $\mathrm{C}_{12} \mathrm{H}_{25} \mathrm{I}$, supporting the findings of Henrich (1981). In addition to this compound, all straight chain alkane iodides from $\mathrm{C}-1$ to $\mathrm{C}-11$ were detected.

\section{Thermodynamic Modeling of Potential lodine Species}

An examination of possible formation pathways for penetrating iodine-bearing species was completed. Thermodynamically favorable reactions were identified using enthalpy $(\mathrm{H})$, entropy $(\mathrm{S})$ and heat capacity (Cp) (HSC) modeling ${ }^{a}$, which uses thermodynamic constants to determine the free energy of a reaction. Inorganic and organic iodine-bearing species were examined independently, and the results are presented in this section.

\subsection{Inorganic lodine Species}

In reactions between iodine and water, several different iodine species have been identified (Clough and Starkie, 1985) including: $\mathrm{I}_{2}, \mathrm{I}^{-}, \mathrm{I}_{3}^{-}, \mathrm{I}_{5}^{-}, \mathrm{I}_{6}^{-}, \mathrm{OI}^{-}, \mathrm{HI}_{2} \mathrm{O}^{-}, \mathrm{I}_{2} \mathrm{O}^{2-}, \mathrm{H}_{2} \mathrm{OI}^{+}, \mathrm{IO}_{3}^{-}, \mathrm{HI}$, and HOI. The ionic forms exist only in the aqueous phase, but their interactions with the solution species directly connected to the volatile species impact the fraction of each volatile species. The primary gas phase forms would be $\mathrm{I}_{2}, \mathrm{HI}$ and HOI. Estimated solubilities of these species are shown in Eqns. 3-1-3-3 of Table 3-1. Hydrolysis of elemental iodine in either the gas phase (Eqn. 3-4) or in the aqueous phase (Eqn. 3-5) is characterized by a very small equilibrium constant; the values in the table are smaller than the value of $4.3 \times 10^{-12}$ reported by Eigen and Kustin (1962), but in general the agreement is that the extent of hydrolysis at equilibrium is very small. The production of $\mathrm{HOI}$ is very favorable if a metal like $\mathrm{Fe}$ is available to participate in a reaction, Eqn. 3-6, or if certain metal oxides are present, an example of which is shown by Eqn. 3-7. Hydrolysis may also be photolytically or radiolytically induced (Buxton and Mulazzani 2007; Vogt et al. 1999). Atomic iodine, a radiolysis product of $\mathrm{I}_{2}$, produces $\mathrm{HOI}$ in a thermodynamically favorable equilibrium (Eqn. 3-8). The high radiation fluxes that exist in dissolver solution, and other places in the plant, would be expected to promote such a reaction. 
Table 3-1. A subset of reactions involving iodine that affect its speciation

\begin{tabular}{|c|c|c|}
\hline Eqn. \# & Reaction & $\mathrm{K}\left(25^{\circ} \mathrm{C}\right)^{a}$ \\
\hline $3-1$ & $\mathrm{I}_{2}(\mathrm{~g}) \rightarrow \mathrm{I}_{2}(\mathrm{aq})$ & 3.38 \\
\hline $3-2$ & $\mathrm{HI}(\mathrm{g}) \rightarrow \mathrm{H}^{+}(\mathrm{aq})+\mathrm{I}^{-}(\mathrm{aq})$ & $2.34 \times 10^{9}$ \\
\hline $3-3$ & $\mathrm{HOI}(\mathrm{g}) \rightarrow \mathrm{H}^{+}(\mathrm{aq})+\mathrm{OI}^{-}(\mathrm{aq})$ & $2.06 \times 10^{-9}$ \\
\hline $3-4$ & $\mathrm{I}_{2}(\mathrm{~g})+\mathrm{H}_{2} \mathrm{O}(\mathrm{g}) \rightarrow \mathrm{HOI}(\mathrm{g})+\mathrm{HI}(\mathrm{g})$ & $3.01 \times 10^{-22}$ \\
\hline $3-5$ & $\mathrm{I}_{2}(\mathrm{~g})+\mathrm{H}_{2} \mathrm{O}(\mathrm{l}) \rightarrow \mathrm{HOI}(\mathrm{g})+\mathrm{H}^{+}(\mathrm{aq})+\mathrm{I}^{-}(\mathrm{aq})$ & $2.23 \times 10^{-14}$ \\
\hline $3-6$ & $\mathrm{Fe}+2 \mathrm{I}_{2}(\mathrm{~g})+\mathrm{H}_{2} \mathrm{O}(\mathrm{g}) \rightarrow \mathrm{FeI}_{2}+\mathrm{HOI}(\mathrm{g})+\mathrm{HI}(\mathrm{g})$ & 27.8 \\
\hline $3-7$ & $\mathrm{HgO}+2 \mathrm{I}_{2}(\mathrm{~g})+\mathrm{H}_{2} \mathrm{O} \rightarrow 2 \mathrm{HOI}(\mathrm{g})+\mathrm{HgI}_{2}$ & $1.55 \times 10^{5}$ \\
\hline $3-8$ & $2 \mathrm{I}(\mathrm{g})+\mathrm{H}_{2} \mathrm{O}(\mathrm{g}) \rightarrow \mathrm{HOI}(\mathrm{g})+\mathrm{HI}(\mathrm{g})$ & 0.481 \\
\hline $3-9$ & $\operatorname{Ag}^{+}(\mathrm{aq})+\mathrm{I}^{-}(\mathrm{aq}) \rightarrow \operatorname{AgI}(\mathrm{s})$ & $1.05 \times 10^{16}$ \\
\hline $3-10$ & $\mathrm{Pd}^{2+}(\mathrm{aq})+2 \mathrm{I}^{-}(\mathrm{aq}) \rightarrow \mathrm{PdI}_{2}(\mathrm{~s})$ & $1.52 \times 10^{25}$ \\
\hline $3-11$ & $2 \mathrm{Ag}^{+}(\mathrm{aq})+2 \mathrm{OI}^{-}(\mathrm{aq}) \rightarrow 2 \mathrm{AgI}(\mathrm{s})+\mathrm{O}_{2}(\mathrm{aq})$ & $8.04 \times 10^{33}$ \\
\hline $3-12$ & $\mathrm{Pd}^{2+}(\mathrm{aq})+2 \mathrm{OI}^{-}(\mathrm{aq}) \rightarrow \mathrm{PdI}_{2}(\mathrm{~s})+\mathrm{O}_{2}(\mathrm{aq})$ & $1.11 \times 10^{27}$ \\
\hline
\end{tabular}

${ }^{a}$ Calculated with HSC Chemistry version 8. Standard free energies of formation are used to calculate the free energy of the reaction, which is used to calculate the equilibrium constant by the relationship $\Delta \mathrm{G}=-\mathrm{RT} \ell \mathrm{n} \mathrm{K}$.

The dissolver solution contains concentrated nitric acid that solubilizes the nuclear fuel and associated fission products. Among these fission products are silver $(\mathrm{Ag})$ and palladium (Pd), and whether they are free metals or oxides in the spent fuel, they will dissolve into solution as $\mathrm{Pd} 2+$ and $\mathrm{Ag}+$. Both $\mathrm{Ag}$ and $\mathrm{Pd}$ combine with aqueous iodide ion and precipitate as solids as shown by the thermodynamically favorable Eqns. 3-9 and 3-10 and as found by Sakurai and coworkers $(1997 ; 1989 ; 1992)$. Formation of these iodides represents a mechanism whereby iodine is removed from solution, shifting Reaction 3-8 to the right and forming more HOI and HI. Silver and Pd may also react with the iodous ion to precipitate the iodide as indicated by Eqns. 3-11 and 3-12, which removes the highly volatile form from solution. This suggests a competition between volatilization and precipitation rates that determines the disposition of HOI.

There are reports of HOI present in the gaseous effluent of both BWR and CANDU reactors, and it has also been observed in nuclear accidents (Marrero 1977; Kabat 1983). Ignoring radiation as an initiator, the hydrolysis reaction (Eqn. 3-5) is slow to moderate (Bell et al. 1982; Clément et al. 2007). If HI were removed from the mixture or solution with sufficient rapidity, the tendency would be to allow more $\mathrm{I}_{2}$ to hydrolyze, and the production of HOI would be limited by the kinetics of the hydrolysis reaction. HOI is volatile in water solution (volatility is the reciprocal of the equilibrium constant shown for Eqn. 3-3) and will distribute to the gas phase accordingly. With sufficient residence time in the liquid solutions and offgas streams, the amount of HOI could be controlled by the kinetics of the formation reactions and removal of co-product species rather than thermodynamic equilibria. Because $\mathrm{HOI}$ is relatively 
unreactive to standard trapping media, there is a need to ascertain what fraction of the iodine in the offgas stream might be converted to that form.

\subsection{Organic lodine Species}

Organic iodides may form in both aqueous and gas phases (Karhu 2001; Nakamura et al. 1973; Taghipour 1999; Wren et al. 1999). Organic compounds may be introduced to the processing systems, such as the dissolver, in small quantities with fresh reagents (e.g., nitric acid) or with recycle acid that might contain small amounts of alkanes (e.g., dodecane) or tri- $n$-butyl phosphate. Radiolysis and/or hydrolysis reduces larger molecules to smaller molecules and produces radicals that react readily with iodine or other species that are present (Mincher et al. 2009; Tripathi et al. 1999; Wright and PavietHartmann 2010). Reactions between methane and molecular iodine are not thermodynamically favorable. However, methane reactions with $\mathrm{HI}$ in the presence of oxygen to produce methyl iodide (Eqn. 3-13 in Table 3-2) are highly favored thermodynamically although this reaction may still be limited by kinetics. Methane reaction with $\mathrm{HOI}$ in the gas phase to produce $\mathrm{CH}_{3} \mathrm{I}$ is very thermodynamically favored (Eqn. 3-14). Because methane and HOI tend to partition to the gas phase, this could be an important reaction. It is possible that similar reactions between other alkanes, such as ethane or propane, and HOI could proceed similarly, producing longer-chain alkyl iodides. Reactions of methane with $\mathrm{NO}_{2}$ produce nitrated species that are also reactive. Methyl nitrate $\left(\mathrm{CH}_{3} \mathrm{NO}_{3}\right)$ is a possible product (Eqn. 3-15), but since it is an explosive compound it probably is not sufficiently stable to persist. Nitromethane $\left(\mathrm{CH}_{3} \mathrm{NO}_{2}\right)$ may be produced in either the gas phase with $\mathrm{NO}_{2}$ (Eqn. 3-16) or in the liquid phase with nitric acid (Eqn. 3-17) and has also been reported by Sakurai and coworkers ( 1996). It may provide another route to produce $\mathrm{CH}_{3} \mathrm{I}$ via reaction with $\mathrm{HI}$ (Eqn. 3-18). Furthermore, thermodynamics indicates $\mathrm{CH}_{3} \mathrm{I}$ is oxidized by $\mathrm{NO}_{2}$ to produce $\mathrm{CH}_{3} \mathrm{NO}_{2}$ and free iodine (Eqn. 3-19). Thus, in modeling the system it will be important to ascertain the mechanisms that either add or remove certain species from the off-gas mixture (e.g., corrosion reactions, condensation, etc.). Nitromethane may react with methyl iodide to produce dimethyl ether $\left(\mathrm{CH}_{3} \mathrm{OCH}_{3}\right)$ and nitrosyl iodide (Eqn. 3-20); the latter is unstable and should rapidly dissociate to $\mathrm{NO}$ and $\mathrm{I}_{2}$ or react with other organics to produce organic iodides. Equation 3-20 may also explain the presence of dimethyl ether observed in some sorption tests (Scheele et al. 1983). Higher alkanes can react with iodine to produce $\mathrm{CH}_{3} \mathrm{I}$ and lower alkanes (Clément et al. 2007) in reactions of the form $2 \mathrm{CH}_{3} \mathrm{R}+\mathrm{I}_{2}=2 \mathrm{CH}_{3} \mathrm{I}+2 \mathrm{R}$. A similar cleaving of alkanes seems to be likely with $\mathrm{HI}$ in the gas phase. The reaction between propane and HI, as an example, is limited to a thermodynamic conversion of about 5\% (Eqn. 3-21). 
Table 3-2. A subset of reactions involving methyl iodide

\begin{tabular}{|l|l|c|}
\hline Eqn. \# & Reaction & $\mathbf{K}^{\left(25^{\circ} \mathbf{C}\right)^{a}}$ \\
\hline $3-13$ & $2 \mathrm{CH}_{4}(\mathrm{~g})+2 \mathrm{HI}(\mathrm{g})+\mathrm{O}_{2}(\mathrm{~g}) \rightarrow 2 \mathrm{CH}_{3} \mathrm{I}(\mathrm{g})+2 \mathrm{H}_{2} \mathrm{O}(\mathrm{g})$ & $2.7 \times 10^{58}$ \\
\hline $3-14$ & $\mathrm{CH}_{4}(\mathrm{~g})+\mathrm{HOI}(\mathrm{g}) \rightarrow \mathrm{CH}_{3} \mathrm{I}(\mathrm{g})+\mathrm{H}_{2} \mathrm{O}(\mathrm{g})$ & $3.5 \times 10^{13}$ \\
\hline $3-15$ & $2 \mathrm{CH}_{4}(\mathrm{~g})+5 \mathrm{NO}_{2}(\mathrm{~g}) \rightarrow 2 \mathrm{CH}_{3} \mathrm{NO}_{3}(\mathrm{~g})+3 \mathrm{NO}(\mathrm{g})+\mathrm{H}_{2} \mathrm{O}(\mathrm{g})$ & $1.8 \times 10^{93}$ \\
\hline $3-16$ & $4 \mathrm{CH}_{4}(\mathrm{~g})+\mathrm{O}_{2}(\mathrm{~g})+4 \mathrm{NO}_{2}(\mathrm{~g}) \rightarrow 4 \mathrm{CH}_{3} \mathrm{NO}_{2}(\mathrm{~g})+\mathrm{H}_{2} \mathrm{O}(\mathrm{g})$ & $1.1 \times 10^{20}$ \\
\hline $3-17$ & $\mathrm{CH}_{4}(\mathrm{aq})+\mathrm{HNO}_{3}(\mathrm{aq}) \rightarrow \mathrm{CH}_{3} \mathrm{NO}_{2}(\mathrm{~g})+\mathrm{H}_{2} \mathrm{O}(\mathrm{l})$ & $3.6 \times 10^{25}$ \\
\hline $3-18$ & $\mathrm{CH}_{3} \mathrm{NO}_{2}(\mathrm{~g})+\mathrm{HI}^{2}(\mathrm{~g}) \rightarrow \mathrm{CH}_{3} \mathrm{I}_{(\mathrm{g})+\mathrm{HNO}_{2}(\mathrm{~g})}$ \\
\hline $3-19$ & $2 \mathrm{CH}_{3} \mathrm{I}(\mathrm{g})+2 \mathrm{NO}_{2}(\mathrm{~g}) \rightarrow 2 \mathrm{CH}_{3} \mathrm{NO}_{2}(\mathrm{~g})+\mathrm{I}_{2}(\mathrm{~g})$ & 48.2 \\
\hline $3-20$ & $2 \mathrm{CH}_{3} \mathrm{NO}_{2}+\mathrm{CH}_{3} \mathrm{I}(\mathrm{g}) \rightarrow \mathrm{CH}_{3} \mathrm{OCH}_{3}+\mathrm{NOI}^{2}(\mathrm{~g})$ & $5.33 \times 10^{-2}$ \\
\hline $3-21$ & $\mathrm{C}_{3} \mathrm{H}_{8}(\mathrm{~g})+\mathrm{HI}(\mathrm{g}) \rightarrow \mathrm{CH}_{3} \mathrm{I}(\mathrm{g})+\mathrm{C}_{2} \mathrm{H}_{6}(\mathrm{~g})$ & 1.3 \\
\hline
\end{tabular}

${ }^{\mathrm{a}}$ Calculated with HSC Chemistry version 8 .

The thermodynamic evaluation given above is not intended to be comprehensive; a full treatment of such a system would be very extensive. Rather, the intent of the discussion is to identify some formation pathways for penetrating iodine forms that could be present in off-gas systems. The equilibrium constants of the reactions demonstrate whether a reaction is thermodynamically favorable but cannot provide insight into the kinetics of each reaction or other affecting factors such as reactant or product sinks, fluctuating temperatures and vapor pressures, and high radiation fields. All of these factors have an impact on the true concentrations of iodine-bearing species present in an off-gas system. The high radiation field that is present throughout a plant is likely to have an especially significant effect as it creates numerous degradation products, radical species, and unusual species (such as atomic I) that can be highly reactive and create other formation pathways not identified here. The chemical interactions are complicated, and with other species such as $\mathrm{NO}_{\mathrm{X}}$ and $\mathrm{Cl}$ (as $\mathrm{HCl}$ ) in relatively greater abundance, additional reactions may take place. The temperature dependence of the reactions may be important because of the range of temperatures in the dissolver, immediate dissolver off-gas, and in the off-gas streams further removed from the hot processes where they are cooled. At minimum, a literature review to identify pertinent reactions, along with experimental data on their equilibria and kinetics, would be required to feed a realistic model.

\section{Sources of iodine vapor species in reprocessing}

The operations of an aqueous-process reprocessing facility were analyzed to determine those that are likely sources of iodine-bearing species present in the off-gas. To simplify this, we start with the headend processes and finish with the waste processes. 


\subsection{Fuel disassembly}

In the fuel, iodine is expected to exist as atomic iodine (I), elemental iodine $\left(\mathrm{I}_{2}\right)$, cesium iodide (CsI) (Birdwell 1990; Birdwell and Weber 1986; Borisov 2004; Dreher et al. 1945; McCracken 1985; McManus et al. 1982), and AgI and $\mathrm{PdI}_{2}$ (Sakurai et al. 1997; Sakurai et al. 1989; Sakurai et al. 1992). Both I (atomic iodine) and $\mathrm{I}_{2}$ are expected to be largely dissolved in the $\mathrm{UO}_{2}$ matrix, while CsI is expected at the pellet-pellet interface and the pellet-cladding interface.

During the disassembly of the fuel rods from the fuel hardware, no release of iodine is expected. Once the fuel hardware has been removed, the fuel is usually chopped into smaller, more easily processed, pieces. Any volatile iodine that accumulated at the fuel pellet-cladding interface or has escaped from a cracked fuel pellet may report to the off-gas stream. This too is expected to be a very small contribution. These fuel pieces are then treated with strong nitric acid to dissolve the fuel meat from the cladding. During this process the iodine is released from the $\mathrm{UO}_{2}$ matrix but not necessarily volatilized.

If tritium voloxidation (Brown 1976; Del Cul et al. 2013; Goode and Stacy 1978) is used in the process of removing the irradiated fuel from the cladding, the iodine is expected to be released as HI. However, under oxidizing conditions, HI can be oxidized to $I_{2}$ through the Deacon reaction (Deacon 1875). The Deacon reaction is discussed in detail in Section 4.4.1.

\subsection{Fuel dissolution}

As stated by Evans and Jervis (1992), iodine released from fuel into an aqueous environment is mostly found as $\mathrm{I}^{-}$, which is nonvolatile. This $\mathrm{I}^{-}$can be oxidized to volatile $\mathrm{I}_{2}$, to HOI which is much less volatile, or the ions of iodate $\left(\mathrm{IO}_{3}^{-}\right)$or periodidate $\left(\mathrm{IO}_{4}^{-}\right)$that are not volatile.

Laboratory studies of fuel dissolution show complete release of iodine, but in practice release of the iodine from the fuel during dissolution may not be quantitative (Mineo et al. 1999a; Mineo et al. 1999b; Morgan and Holland 1980). The majority of the iodine ( $>80 \%)$ is volatilized as $\mathrm{I}_{2}$ or HI. Results from studies with irradiated fuel at Oak Ridge National Laboratory (ORNL) support the findings of these cited studies (Burch et al. 1977; Jubin et al. 2013).

Sakurai and coworkers $(1989 ; 1990 ; 1995 ; 1996 ; 1993)$ found that a significant quantity of the iodine inventory $(\sim 3 \%)$ precipitated as colloidal material, mainly as $\mathrm{PdI}_{2}$ and $\mathrm{AgI}$ or sorbed on other insoluble material in the dissolver. These are not volatile at this stage of the reprocessing, but, if they are not volatilized or dissolved, they become part of the undissolved solids (UDS) in the dissolver that are ultimately destined for the glass melter.

Sakurai and coworkers $(1983 ; 1984)$ found that $\mathrm{NO}_{2}$ that may be present in the dissolver or DOG reacted with the organic iodides to form nitrated organics and $\mathrm{I}_{2}$. However, their results indicated that a zeolite or similar substrate was needed to facilitate the reaction. Requirement of a catalyst to facilitate this reaction is supported by the results of Nenoff et al. (2014). The thermodynamics of interactions of organic iodides with $\mathrm{NO}_{2}$ suggests that the reaction may proceed even in the absence of a catalyst (Scheele 1973).

Hasty (1967) studied the behavior of $\mathrm{CH}_{3} \mathrm{I}$ (often used as a surrogate for the organic iodides in the system) with temperature. At 30 to $50^{\circ} \mathrm{C}$ and chemical equilibrium, $\mathrm{CH}_{3} \mathrm{I}$ was present in the aqueous phase at concentrations two to three times higher than its concentration in the vapor phase. This indicates that efforts to volatilize $\mathrm{CH}_{3} \mathrm{I}$ or other organic iodides into the DOG may have limited success. As stated in Section 2.2, commercially obtained nitric acid contains organic impurities, and these impurities are known to react with iodine in the dissolver solution (Nakamura 1973). As the long-chain alkyl iodides do not volatilize into the DOG, residual organic iodine-bearing species may accumulate in the dissolver solution and be released into the VOG during solvent extraction processes. 


\subsection{Solvent extraction processes}

A substantial fraction ( 70 to $80 \%$ ) of the iodine remaining in the dissolver solution is extracted into the organic phase during solvent extraction (Sakurai et al. 1995). This fraction is independent of radiation dose. The solvent extraction process currently used in Plutonium Uranium Redox Extraction (PUREX)type reprocessing facilities is a likely source for organoiodine species. Radiolysis causes the decomposition of the tributylphosphate, the dodecane $\left[\mathrm{CH}_{3}\left(\mathrm{CH}_{2}\right)_{10} \mathrm{CH}_{3}\right]$ diluent, and other organics in the facility (Mincher and Mezyk 2009; Tripathi et al. 1999; Wright and Paviet-Hartmann 2010). As the radiation exposure increases for dodecane and the subsequent degradation product undecane $\left[\mathrm{CH}_{3-}\right.$ $\left(\mathrm{CH}_{2}\right)_{9} \mathrm{CH}_{3}$ ], the amounts of radiolysis products increase (Ikeda and Suzuki 2001; Ikeda and Suzuki 1998; Mincher and Mezyk 2009; Tripathi et al. 1999; Wright and Paviet-Hartmann 2010). These consist of complex organic species that are preceded by methyl $\left(\mathrm{CH}_{3}{ }^{\circ}\right)$ and ethyl $\left(\mathrm{CH}_{3} \mathrm{CH}_{2}\right)$ free radicals (Ikeda 2001; Ikeda 1998; Mincher 2009; Tripathi 1999). Some of the highly reactive decomposition products are likely to react with any iodine present. Many of the iodides that result from these interactions are expected to remain with the organic phase (Sakurai et al. 1995), even when the organic phase is washed to remove the radiolytic decomposition products.

Nakamura et al. (1973) found an extensive suite of organic iodides in their studies of nitric acid containing iodine. These included $\mathrm{CH}_{3} \mathrm{I}, \mathrm{C}_{2} \mathrm{H}_{3} \mathrm{I}, \mathrm{C}_{2} \mathrm{H}_{5} \mathrm{I}, n-\mathrm{C}_{3} \mathrm{H}_{7} \mathrm{I}$, and $n-\mathrm{C}_{4} \mathrm{H}_{9} \mathrm{I}$. These were studied involving just nitric acid and iodine; no fuel was present. This highlights the complexity of the iodine chemistry that is possible in a reprocessing facility. With acid recycle and the presence of radiolytic decomposition products, it is very likely that the studies in which organic iodides were determined at actual reprocessing facilities did not discover these higher molecular weight organics or they existed at sufficiently low concentrations and eluded detection. It is important to note that longer chain alkyl iodides have relatively high vapor pressures and, if present, are likely to release into the VOG during solvent extraction processes to some extent. However, if the facility is designed to attain the maximum iodine decontamination factor (3000) needed to meet current regulations, sources of small fractions of iodine become important (Jubin et al. 2012), and see the discussion in Section 1.2.

Herrmann et al. (1997) found that very little of the iodine in the organic solvent was removed in the organic wash $\left(\mathrm{Na}_{2} \mathrm{CO}_{3}\right)$ during solvent cleanup. About $50 \%$ was released to the VOG. About $2-6 \mu \mathrm{g} / \mathrm{m}^{3}$ of iodine was found in the vent systems of the high-level waste storage tanks. Caustic scrubbing was ineffective at removing iodine from the DOG-only about $15 \%$ was removed. This suggested that much of the iodine in the VOG was in forms, such as organic iodides, that were not highly soluble in caustic, compared to iodine forms such as $\mathrm{I}_{2}$ and $\mathrm{HI}$ that are quite soluble.

\subsection{Waste management areas}

The assessment of evolution of iodine-bearing compounds from the waste treatment/immobilization operations assumes that the organic waste undergoes volume reduction with incineration and the inorganic wastes, including the UDS, are processed in a high-temperature glass melter.

A significant factor affecting the presence of low-sorbing iodine species in these waste streams is that the partitioning of iodine into manufactured waste forms or into easily captured particulates is largely unknown. However, this section will still address conditions present in waste management processes that might be favorable for the formation of low-sorbing iodine species. 


\subsubsection{Organic disposal}

The assumption for the treatment of waste organics is that they are incinerated and the remaining ash mixed with concrete. If the iodo-organics mimic the other halogenated organics, such as polyvinyl chloride, some of the iodine is expected to stay with the fly ash or oils (Hall and Williams 2006) that result from incineration or pyrolysis of organics. Schindler (1981) showed that TBP and solvent could be successfully destroyed with any of a variety of process options. Although there were small amounts of chlorine and fluorine in the simulated wastes, the fate of the halides was not reported. During the incineration process, the organic compounds are expected to be completely destroyed (Alexander et al. 1998; Brady 1992; Naba and Imao 1993; Soelberg et al. 1997). From 70 to 80\% of the iodine is volatilized (Brady 1992). Since the organic iodides are expected to be destroyed, the iodine is expected to be in the form of inorganic iodides. Alexander and coworkers (1998) found that the likely off-gas compounds for iodine were $\mathrm{HI}$ and $\mathrm{I}_{2}$ although $\mathrm{ICl}$ could also be present. Wikström et al. (2000) showed that incineration of municipal wastes resulted in complex halogenated organics. Thus, depending on the compounds being incinerated and the process by which they are destroyed, the iodine-bearing compounds can vary from inorganic to organic.

While there is a lack of literature on the fate of iodine from halogenated organics, there is also a dearth of information on the fate of chlorine. Deacon (1875) filed a patent on the oxidation of $\mathrm{HCl}$ to $\mathrm{Cl}_{2}$ in the presence of water. This reaction, known as the "Deacon Reaction" or "Deacon Process" has been cited in several studies of municipal incineration and halogenated organic combustion studies (Perez-Ramirez et al. 2011; Seki 2010) as being the source of chlorinated organics and of $\mathrm{Cl}_{2}$ in the stack gases (Wikström and Marklund 2000; Perez-Ramirez et al. 2011; Seki 2010). From the literature, iodine appears to be as or more reactive in these gas streams and in the atmosphere as is chlorine. This could imply that organic iodides might be expected in the WOG, especially if conditions are oxidizing and humid leading to the formation of $\mathrm{I}_{2}$ or ICl. The latter is possible since chlorine is expected to be present at concentration many times that of iodine.

\subsubsection{Glass melter}

There are five basic designs for high-level waste (HLW) melter systems including: (1) hot wall induction melter, (2) hot wall resistance melter, (3) cold-crucible induction melter (CCIM), (4) liquid-fed ceramic melter (LFCM), and the in-canister melter (Vienna et al. 2015). The design and operating conditions of the melter, as well as the HLW waste feed process, can determine how the iodine in the HLW evolves and speciates in the melter off-gas stream.

A variation on the CCIM used in France involves calcining the waste with the hot melter off-gas to remove the volatiles and water. The calcine is mixed with glass frit as it enters the melter and typically forms a cold cap on the glass melt that dissolves into the molten glass. Iodine species in the calciner feed can begin to react and volatilize in the calciner. Any iodine that does not volatilize in the calciner and does not incorporate into the glass can react and volatilize in the melter and pass with the melter off-gas as volatile species or as species in entrained dust through the calciner, exiting with the calciner off-gas.

In the LFCM concept used in the United States, the liquid feed is mixed with a glass frit or mixed with glass-formers, and the mixture is fed to the top of a glass melt where it forms a cold cap that dissolves into the molten glass. As the materials in the cold cap are heated, various chemical reactions occur that result in the volatilization of iodine as $\mathrm{I}_{2}$ or mixed halides, e.g., ICl (Burger and Scheele 2004), which exits with the melter off-gas. Some of the iodine may be incorporated in the entrained dust; and some of the iodine might be incorporated into the glass. Oh (2011) indicates that the amount of iodine incorporated into the glass may be quite small ( $<1$ mass $\%$ for silicate glasses).

Options for handling the dissolver UDS, which are expected to contain precipitated inorganic and organic iodides, include vitrification along with the HLW, or melting into a metal waste form (Vienna et al. 
2015). In both liquid-fed or solid/slurry-fed glass or metal melter designs, the iodine-bearing UDS, e.g., $\mathrm{PdI}_{2}$ and $\mathrm{AgI}$ (Sakurai et al. 1989; Sakurai et al. 1990), are expected to decompose to elemental iodine or mixed halides if excess $\mathrm{Cl}$ is present. These species would be subsequently volatilized.

Volatilization of iodine from the melter to the MOG system depends on how much iodine might be incorporated in the glass, into particulate matter in the off-gas system (that is eventually captured in scrubber effluents or in particulate filters), and how much is volatilized, forming gaseous species such as $\mathrm{I}_{2}$, ICl, HI, HOI, and organic iodides. Because of the relatively high temperatures and estimated low affinity of glass for iodine, it is conservative to assume that, like municipal waste incinerators, inorganic and organic iodides and other halides evolve to the off-gas (Wang et al. 2007; Wikström and Marklund 2000) or from pyrolysis (Barton and Mordy 1984; Grossi et al. 2007; Hall and Williams 2006; Ravindran et al. 1997; Yang et al. 2013).

Iodine speciation in the MOG can be affected by the MOG system unit operations that are required for cooling, filtering, and scrubbing the off-gas to meet regulatory requirements regardless of the requirement for iodine emissions control. Future MOG systems are expected to require the following unit operations:

- Wet scrubbing and mist elimination (acid scrubbing followed by caustic scrubbing, or else caustic scrubbing, which further cools the off-gas and scrubs particulate matter and some acid gases with up to $99.9 \%$ efficiency); acid scrubbing will scrub some iodine species such as HI, and caustic scrubbing will scrub $\mathrm{HI}, \mathrm{I}_{2}, \mathrm{ICl}$, and possibly others.

- Reheating (to at least $20^{\circ} \mathrm{C}$ above the water dew point to prevent condensation in downstream operations); since reheating is normally moderate, this is not expected to affect iodine species.

- High efficiency particulate arrestance or air (HEPA) filtration (to capture particulate-phase radionuclides with at least $99.9 \%$ efficiency); this will efficiently remove particulate-phase iodine species.

- Oxidation (catalytic or thermal, to destroy hydrocarbons); normally performed at temperatures of $\sim 500^{\circ} \mathrm{C}$ (catalytic) or $800-1000^{\circ} \mathrm{C}$ (thermal), this can destroy organic iodides, if present.

These unit operations, designed to control particulate matter, radionuclides, acid gases including halides and $\mathrm{NO}_{\mathrm{x}}$, and hydrocarbons, can significantly change the speciation of, or remove, iodine species in the MOG prior to any additional iodine control technology.

\subsubsection{Calciner}

The speciation of iodine in the off-gas from the Waste Calcining Facility calciner (operated at the Idaho National Laboratory between 1961 and 1981) and released to the stack (after HLW calcination at temperatures between $400-500^{\circ} \mathrm{C}$, acid gas scrubbing, sorption on silica gel, and filtration through HEPA filters) was estimated to be $15 \% \mathrm{I}_{2}, 21 \% \mathrm{HOI}$, and $64 \%$ organic iodine (McManus et al. 1982). As discussed in the previous section, halogenated organics from this process cannot be ruled out since no reported studies of their presence have been published. This range of speciation could be indicative of iodine species from a moderately low-temperature thermal process that can pass through acid gas scrubbing, silica gel adsorption, and HEPA filtration processes.

\subsection{4 lodine waste form production}

Because of the long half-life of ${ }^{129} \mathrm{I}$, long-term disposal of materials containing ${ }^{129} \mathrm{I}$ is likely to require the development of an iodine-retaining waste form. No matter which process is selected for the immobilization of ${ }^{129} \mathrm{I}$, an iodine off-gas treatment process is likely to be required. These process(es) need to be analyzed to determine the potential gaseous compounds containing iodine so that the DF of the 
iodine trap methodology can be determined. The iodine immobilization technology is very early in the development stage, limiting the ability to forecast the likely iodine bearing species that might be generated.

\section{Summary of iodine species and sources}

Based on the results of the literature survey and some limited thermodynamic modeling, the inorganic iodine species HOI and ICl were identified as iodine species that could present in off-gas systems. Organic species of interest included both short chain alkyl iodides such as methyl iodide $\left(\mathrm{CH}_{3} \mathrm{I}\right)$ and longer alkyl iodides such as iodododecane $\left(\mathrm{C}_{12} \mathrm{H}_{25} \mathrm{I}\right)$. Both inorganic and organic iodine-bearing species will be released into the off-gas by various processes throughout the plant.

Fuel dissolution may provide conditions conducive to HOI formation and has been proven to generate long-chain alkyl iodides although these may not volatilize until later in the reprocessing sequence. Solvent extraction processes are expected to be significant sources of various organic iodine-bearing species; formation of these is facilitated by the presence of radiolytic decomposition products resulting from radiolysis of tri- $n$-butyl phosphate and dodecane. Primarily inorganic iodine compounds are expected from waste management processes, including chlorinated species such as ICl.

In the recycle of $\mathrm{HNO}_{3}$, the organics that are dissolved into or entrained in the acid contain organic iodides, some of which are volatile. Hence, these organic iodides can be either volatilized in the dissolver or precipitated in either organic or inorganic forms. If tritium pretreatment is used, the only penetrating form of iodine that would be expected in the DOG is HOI since tramp organics are not expected nor is tramp chlorine. This could be formed from the reaction of $I_{2}$ with water either in aerosols or with water vapor according to Eqn. 2-1. In the absence of tritium pretreatment, the likely inorganic form would be HOI, again by Eqn. 2-1.

Once the dissolver solution containing iodine leaves the dissolver, a substantial amount of the iodine is transferred to the organic phase during solvent extraction and only about $50 \%$ is transferred back to the aqueous-phase strip solution; virtually none is removed during washing of the organic (Sakurai et al. 1987; Sakurai et al. 1997; Sakurai et al. 1989; Sakurai et al. 1990; Sakurai et al. 1995; Sakurai et al. 1992).

From the literature on the forms of iodine in the atmosphere and in reprocessing facilities and the tramp organics that come with the $\mathrm{HNO}_{3}$ or with the recycled acid, $\mathrm{CH}_{3} \mathrm{I}$ is likely to exist, but higher molecular weight organic iodides are also likely and may be predominant. It is highly likely that these higher molecular weight organic iodides, including mixed halide forms, are less reactive than $\mathrm{CH}_{3} \mathrm{I}$ whether thermodynamically or kinetically. Hence, these might be expected to be a challenge for iodine removal in an iodine removal system. Under the aqueous processing conditions currently envisioned, up to $5 \%$ of the iodine inventory may be in the undissolved solids in the fuel dissolver. These organic and inorganic iodides would go to the glass melter unless some other process is installed intermediate to the melter, e.g., separate processing of the undissolved solids to produce a metal waste form (Crum et al. 2013; Ebert et al. 2011). If these processes, like the vitrification process, are high temperature, then the likely form of iodine is $\mathrm{I}_{2}$ and $\mathrm{HOI}$, depending on the treatment of the off-gas stream. However, depending on the process by which the liquid waste with UDS is processed (i.e., calciner or heated-glass cold cap) the halogenated organics could volatilize or the volatilized organics could react with the iodine in the gas phase to produce halogenated organics. Similarly, incineration of the waste organics could lead to the inorganic form, HOI, depending on how the off-gas stream is treated; organic forms should be destroyed. 


\section{Conclusions}

This document has detailed the potential sources and types of potentially low-sorbing iodine-bearing compounds that, based on known chemistries, are possible in the off-gas streams of a UNF reprocessing facility. These sources are the DOG, the VOG, and the WOG (with a substantial contribution from the MOG). The species that may form are $\mathrm{HOI}, \mathrm{ICl}$, and alkyl iodides of varying chain length from $\mathrm{CH}_{3} \mathrm{I}$ (methyl iodide) to $\mathrm{C}_{12} \mathrm{H}_{25} \mathrm{I}$ (iodododecane).

Critical knowledge gaps that must still be addressed include confirmation of the existence and, if possible, quantification of low-sorbing species in the off-gas of reprocessing facilities. In many cases, confirmation of their presence is a difficult analytical problem as iodine-bearing species are a function of process environment and may evolve over time and distance from point of origin in plant before reaching the iodine traps due to gas phase reactions with other volatile compounds. Beyond confirmation, quantification of these species may also be desired; the contributions from penetrating forms of iodine to the plant DF are largely unknown and highly dependent on the magnitude of their presence. Closure of these knowledge gaps would allow for better analysis of the contribution that penetrating forms of iodine may have on achieving the desired overall plant target DF.

Importantly, analysis of the potential contributions of each off-gas stream to the overall plant DF showed that the ability to trap iodine from the VOG and COG may be a limiting factor to the overall plant DF. Iodine is present in very dilute concentration in the VOG which can negatively affect its abatement. Additionally, the VOG stream is also the most likely to contain a significant fraction of penetrating iodine-bearing species. These two factors may complicate the efficient abatement of iodine in the VOG and COG streams.

Upon confirmation of the species present in an off-gas system, characterization of their behavior throughout the iodine abatement system should be performed. This report indicates that penetrating iodine-bearing species may respond differently than elemental iodine to current capture technology. These species are likely to be more difficult to remove, and it is likely that their sequestration could be improved through the use of different sorbents, through design modifications of the off-gas capture system, or through chemical conversion prior to iodine abatement that would produce more easily captured forms. This type of research will be valuable in determining the impact that potentially penetrating iodine species have on the DF of a reprocessing facility and will allow design of a facility that can provide the highest quality of iodine abatement.

The authors would like to acknowledge Jim Neeway (PNNL) for creation of Figure 2-1.

\section{Bibliography}

Ackley, RD and RE Adams. 1969. Trapping of Radioactive Methyl/Iodide from Flowing Steam-Air: Westinghouse Test Series. Report No. ORNL-TM-2728, Oak Ridge National Laboratory, Oak Ridge, TN.

Ackley, RD and Z Combs. 1973. Applicability of Inorganic Sorbents for Trapping Radioiodine from LMFBR Fuel Reprocessing Off-Gas. Report No. ORNL/TM-4227, Oak Ridge National Laboratory, Oak Ridge, TN.

Adams, RE, RD Ackley, and WE Browning, Jr. 1967. Removal of Radioactive Methyl Iodide from SteamAir Systems. Report No. ORNL-4040, Oak Ridge National Laboratory, Oak Ridge, TN. 
Aldahan, A, A Kekli, and G Possnert. 2006. "Distribution and Sources of ${ }^{129}$ I in Rivers of the Baltic Region." Journal of Environmental Radioactivity 88(1):49-73.

Alexander, ML, MR Smith, JS Hartman, A Mendoza, and DW Koppenaal. 1998. "Laser Ablation Inductively Coupled Plasma Mass Spectrometry." Appl. Surf. Sci. 127-129:255-61. 10.1016/S01694332(97)00640-5.

Atkins, DHF and AEJ Eggleton. 1963. Iodine Compounds Formed on Release of Carrier-Free Iodine131. Report No. AERE-M-1211, Atomic Energy Research Establishment, Harwell, UK.

Baker, AR, C Tunnicliffe, and TD Jickells. 2001. "Iodine Speciation and Deposition Fluxes from the Marine Atmosphere." Journal of Geophysics Research: Atmosphere 106(D22):28743-49. 10.1029/2000JD000004.

Barnes, I, KH Becker, and J Starcke. 1992. "FTIR Spectroscopic Observation of Gaseous Hypoiodous Acid (HOI)." Chem. Phys. Lett. 196(6):578-82. 10.1016/0009-2614(92)85997-O.

Barton, TG and JA Mordy. 1984. "The Destruction of Halogenated Organic Chemicals by Plasma Pyrolysis." Can. J. Physiol. Pharmacol. 62(8):976-8. 10.1139/y84-165.

Bell, JT, MH Lietzke, and DA Palmer. 1982. Predicted Rates of Formation of Iodine Hydrolysis Species at $p H$ Levels, Concentrations, and Temperatures Anticipated in LWR Accidents. Report No. ORNL5876; NUREG/CR-2900, Oak Ridge National Laboratory, Oak Ridge, TN.

Berliner, E. 1951. "Kinetics of the Iodination of Phenol." Journal of the American Chemical Society 73:4307-11. 10.1021/ja01153a083.

Birdwell, JF. 1990. Iodine and $\mathrm{NO}_{\mathrm{x}}$ Behavior in the Dissolver Off-Gas and IODOX (Iodine Oxidation) Systems in the Oak Ridge National Laboratory Integrated Equipment Test Facility. In Proceedings of the $21^{\text {st }}$ DOE/NRC Nuclear Air Cleaning Conference (CONF-900809-1), 299-314 pp. Harvard Air Cleaning Laboratory, Cambridge, MA.

Birdwell, JF and FE Weber. 1986. Partitioning of Iodine in Offgas Generated by Dissolution of Spent Nuclear Fuel. In Proceedings of the $19^{\text {th }}$ DOE/NRC Nuclear Air Cleaning Conference, 717-29 pp. The Harvard Air Cleaning Laboratory, Cambridge, MA.

Borisov, NB. 2004. "Investigation of Gaseous Fractions of Radioactive Iodine." Atomic Energy 97(5):761-66. 10.1007/s10512-004-0005-5.

Boukis, N, and E Henrich. 1991a. "2-Step Procedure for the Iodine Removal from Nuclear-Fuel Solutions." Radiochimica Acta 55(1): 37-42.

Boukis, N, and E Henrich. 1991b. "I-129 Analysis in Nuclear-Fuel Solutions." Radiochimica Acta 54(2): 103-08.

Brady, JD. 1992. Fate of Tritium, Carbon-14, and Iodine-131 in Wet Scrubber Air Pollution Control Systems on Chemical and Medical Waste Incinerators. In Proceedings of the $11^{\text {th }}$ Incineration Conference: Thermal Treatment of Radioactive Hazardous Chemical, Mixed and Medical Wastes, 395$404 \mathrm{pp}$. University of California, Irvine, Irvine, CA.

Broothaerts, J, G Collard, A Bruggeman, WRA Goossens, LH Baetsle, and R Glibert. 1976. Treatment and Control of Gaseous Effluents from Light Water Reactors and Reprocessing Plants. In Proceedings of the Management of Radioactive Wastes from the Nuclear Fuel Cycle, 101-14 pp. International Atomic Energy Agency, Vienna, Austria.

Brown, RA. 1976. Management of Tritium and Carbon-14. In Proceedings of the International Symposium on the Management of Wastes from the LWR Fuel Cycle (CONF-76-0701), 364-81 pp. US Energy Research and Development Administration, Washington, DC. 
Browning, WE, Jr, RE Adams, RD Ackley, ME Davis, and JE Attrill. 1965. Identity, Character, and Chemical Behavior of Vapor Forms of Radioiodine [CONF-650407 (Vol. 2)]. In Proceedings of the International Symposium on Fission Product Release and Transport Under Accident Conditions, 1131-61 pp. Oak Ridge National Laboratory, Oak Ridge, TN.

Browning, WE, Jr, RE Adams, and JG Wilhelm. 1964. "Investigation of Occurrence and Behavior of Volatile Compounds of Iodine." In Nuclear Safety Program Semiannual Progress Report for Period Ending June 30, 1964, ORNL-3691. Oak Ridge National Laboratory, Oak Ridge, TN.

Browning, WE, Jr. 1963. "Removal of Radioiodine from Gases." Nuclear Safety 6(3):272-79.

Browning, WE, Jr., RD Ackley, and RE Adams. 1963. Nuclear Safety Program Semiannual Progress Report. Report No. ORNL-3547, Oak Ridge National Laboratory, Oak Ridge, TN.

Burch, WD, MJ Feldman, WS Groenier, and BL Vondra. 1977. Advance Fuel Recycle Program Progress Report for Period April 1 to June 30, 1977. Report No. ORNL-TM-5993, Oak Ridge National Laboratory, Oak Ridge, TN.

Burger, LL and RD Scheele. 2004. HWVP Iodine Trap Evaluation. Report No. PNNL-14860, Pacific Northwest National Laboratory, Richland, WA.

Buxton, GV and QG Mulazzani. 2007. "On the Hydrolysis of Iodine in Alkaline Solution: A Radiation Chemical Study." Radiation Physics and Chemistry 76(6):932-40. 10.1016/j.radphyschem.2006.06.009.

Campos, MLAM, PD Nightingale, and TD Jickells. 1996. "A Comparison of Methyl Iodide Emissions from Seawater and Wet Depositional Fluxes of Iodine over the Southern North Sea." Tellus, Series B: Chemical and Physical Meteorology 48B(1):106-14. 10.3402/tellusb.v48i1.15830.

Cartan, F, HR Beard, FA. Duce, and JH Keller. 1968. Evidence for the Existance of Hypoiodous Acid as a Volatile Iodine Species Produced in Water-Air Mixtures. In Proceedings of the Tenth AEC Air Cleaning Conference, 342-53 pp. The Harvard Air Cleaning Laboratory, Cambridge, MA.

Castleman, AW, Jr., IN Tang, and HR Munkelwitz. 1965. Chemical Reactions and Transport Behavior of Fission-Product Iodine. Report No. BNL-9173, Brookhaven National Laboratory, Brookhaven, NY.

Chamberlain, AC, AEJ Eggleton, WJ Megaw, and JB Morris. 1963. "Physical Chemistry of Iodine and Removal of Iodine from Gas Streams." Journal of Nuclear Engineering, Parts A/B Pt. A/B 17(1112):519-50. 10.1016/0368-3230(63)90066-1.

Chameides, WL and DD Davis. 1980. "Iodine: Its Possible Role in Tropospheric Photochemistry." JGR, J. Geophys. Res., [Sect.] C 85(C12):7383-98.

Chang, H-s, C Xu, KA Schwehr, S Zhang, DI Kaplan, JC Seaman, C Yeager, and PH Santschi. 2014. "Model of Radioiodine Speciation and Partitioning in Organic-Rich and Organic-Poor Soils from the Savannah River Site." J. Environ. Chem. Eng. 2(3):1321-30. 10.1016/j.jece.2014.03.009.

Choi, BS, GI Park, JH Kim, JW Lee, and SK Ryu. 2001. "Adsorption Equilibrium and Dynamics of Methyl Iodide in a Silver Ion-Exchanged Zeolite Column at High Temperatures." Adsorption 7(2):91103.

Clément, B, L Cantrel, G Ducros, F Funke, L Herranz, A Rydl, G Weber, and C Wren. 2007. State of the Art Report on Iodine Chemistry. Report No. NEA/CSNI/R(2007)1, Organisation for Economic Cooperation and Development, Paris, France.

Collins, CD, AE Gravett, and JNB Bell. 2004. "The Deposition and Translocation of Methyl Iodide by Crops." Health Phys. 87(5):512-16. 10.1097/01.HP.0000137177.99193.8f. 
Craig, DK, HWW Adrian, and DJJC Bouwer. 1970. "Effect of Iodine Concentration on the Efficiency of Activated Charcoal Adsorbers." Health Phys. 19(2):223-33. 10.1097/00004032-197008000-00002.

Crum, JV, D Strachan, A Rohatgi, and M Zumhoff. 2013. "Epsilon Metal Waste Form for Immobilization of Noble Metals from Used Nuclear Fuel." Journal of Nuclear Materials 441(1-3):103-12.

Deacon, H. 1875. "Improvement in Manufacture of Chlorine." Patent No. US165 802.

Del Cul, GD, JA Johnson, BB Spencer, and ED Collins. 2013. Roadmap for Development of an Advanced Head-End Process. In Proceedings of the International Nuclear Fuel Cycle Conference, 879-81 pp. American Nuclear Society, La Grange Park, IL.

Dexter, AH, AG Evans, and LR Jones. 1977. Iodine Evaporation from Irradiated Aqueous Solutions Containing Thiosulfate Additive. In Proceedings of the Fourteenth ERDA Air Cleaning Conference, 224-32 pp. The Harvard Air Cleaning Laboratory, Cambridge, MA.

Dillmann, HG, H Pasler, and JG Wilhelm. 1990. "Filtered Venting for German Power Reactors." Nuclear Technology 92(1):40-9.

Dreher, JL, MF Acken, and SG Thompson. 1945. The Evolution of Iodine During Metal Dissolution. Report No. HW-3-3003 (Memorandum Report SE-PC-\#74), Atomic Energy Commission, Richland, WA.

Ebert, WL, JC Cunnane, SM Frank, and MJ Williamson. 2011. "Immobilization of Tc in a Metallic Waste Form." Ceram. Trans. 224(Materials Challenges in Alternative and Renewable Energy):291-304.

Eigen, M and K Kustin. 1962. "Kinetics of Halogen Hydrolysis." Journal of the American Chemical Society 84:1355-61. 10.1021/ja00867a005.

Emerson, HP, C Xu, Y-F Ho, S Zhang, KA Schwehr, M Lilley, DI Kaplan, PH Santschi, and BA Powell. 2014. "Geochemical Controls of Iodine Uptake and Transport in Savannah River Site Subsurface Sediments." Applied Geochemistry 45:105-13. 10.1016/j.apgeochem.2014.03.002.

EPA. 2010. Chapter 40. Environmental Protection Agency: Part 61--National Emission Standards for Hazardous Air Pollutants. Subpart H-National Emission Standards for Emissions of Radionuclides Other Than Radon from Department of Energy Facilities. 92 - Standard. 40CFR61.92. US Environmental Protection Agency, Washington, DC.

Evans, GJ and RE Jervis. 1992. "Radiochemical Studies of Iodine Behavior under Conditions Relevant to Nuclear Reactor Accidents." Journal of Radioanalytical and Nuclear Chemistry 161(1):121-33. 10.1007/BF02034886.

Filistovic, V and T Nedveckaite. 1998. "Reaction Pathways Involving ${ }^{127} \mathrm{I}$ and ${ }^{131} \mathrm{I}$ in the Atmospheric Air." Environmental Physics 20(2):5-12.

Goode, JH and RG Stacy. 1978. Head-End Reprocessing Studies with H.B. Robinson-2 Fuel. Report No. ORNL/TM-6037, Oak Ridge National Laboratory, Oak Ridge, TN.

Grossi, V, R de Mesmay, A Galtayries, D Raphel, and S Derenne. 2007. "Artificial Formation of Medium and Long Chain 1-Haloalkanes During Pyrolysis of Polar Geomacromolecules." Org. Geochem. 39(3):342-52. 10.1016/j.orggeochem.2007.11.007.

Hall, WJ and PT Williams. 2006. "Fast Pyrolysis of Halogenated Plastics Recovered from Waste Computers." Energy Fuels 20(4):1536-49. 10.1021/ef060088n.

Harrell, JR, JB Lutz, and JL Kelly. 1988. "On the Volatility and Disproportionation of Hypoiodous Acid." Journal of Radioanalytical and Nuclear Chemistry 127(1):13-20. 10.1007/BF02165501.

Hasty, RA. 1967. The Partition Coefficient of Methyl Iodide between Vapor and Water. Report No. BNWL-SA-1293, Pacific Northwest Laboratory, Richland, WA. 
Hebel, W and G Cottone. 1982. Radioactive Waste Management, Vol. 7: Management Modes for Iodine-129. Harwood Academic.

Henrich, E, H Schmieder, W Roesch, and F Weirich. 1981. Improved Iodine and Tritium Control in Reprocessing Plants. In Proceedings of the 16th DOE Nuclear Air Cleaning Conference, 612-27 pp. The Harvard Air Cleaning Laboratory, Cambridge, MA.

Herrmann, B, V Motoi, H Fies, B Stojanik, J Furrer, and R Kaempffer. 1988. Testing an Iodine Filter for the Vessel Offgas of the German Industrial-Scale Reprocessing Plant (NUREG/CP-0098,

CONF-880822). In Proceedings of the $20^{\text {th }}$ DOE/NRC Nuclear Air Cleaning Conference, 234-46 pp. The Harvard Air Cleaning Laboratory, Cambridge, MA.

Herrmann, FJ, B Herrmann, KD Kuhn, A van Schoor, M Weishaupt, J Furrer, and W Knoch. 1997. Control of Radio-Iodine at the German Reprocessing Plant WAK During Operation and after Shutdown. In Proceedings of the 24 $4^{\text {th }}$ DOE/NRC Nuclear Air Cleaning and Treatment Conference, 618-27 pp. The Harvard Air Cleaning Laboratory, Cambridge, MA.

Hodotsuka, M, XY Yang, H Okuda, and K Onuki. 2008. "Vapor-Liquid Equilibria for the HI+H(2)O System and the HI+H(2)O+I(2) System." Journal of Chemical and Engineering Data 53(8):1683-87. $10.1021 / \mathrm{je} 700544 \mathrm{w}$.

Hou, X, V Hansen, A Aldahan, G Possnert, OC Lind, and G Lujaniene. 2009. "A Review on Speciation of Iodine-129 in the Environmental and Biological Samples." Analytica Chimica Acta 632(2):181-96. 10.1016/j.aca.2008.11.013.

Hrma, P. 2010. Retention of Halogens in Waste Glass. Report PNNL-19361, Pacific Northwest National Laboratory, Richland, WA.

Hu, QH, JE Moran, and JY Gan. 2012. "Sorption, Degradation, and Transport of Methyl Iodide and Other Iodine Species in Geologic Media." Applied Geochemistry 27(3):774-81.

10.1016/j.apgeochem.2011.12.022.

Ikari, M, Y Matsui, Y Suzuki, T Matsushita, and N Shirasaki. 2015. "Removal of Iodide from Water by Chlorination and Subsequent Adsorption on Powdered Activated Carbon." Water Research 68:227-37.

Ikeda, H and A Suzuki. 2001. "Empirical Correlations for Radiolytic Degradation of N-Dodecane. Density, Viscosity and Phase Separation Time." J. Nucl. Sci. Technol. 38(12):1138-40.

10.1080/18811248.2001.9715148.

Ikeda, I and A Suzuki. 1998. "Radiolysis of N-Dodecane and Its Physical Property Change Based on the Dose in One Pass through a Reference Ha Column." J. Nucl. Sci. Technol. 35(10):697-704.

10.1080/18811248.1998.9733930.

Jabbar, T, G Wallner, and P Steier. 2013. "A Review on ${ }^{129}$ I Analysis in Air." Journal of Environmental Radioactivity 126:45-54. 10.1016/j.jenvrad.2013.07.013.

Jubin, R,T, DM Strachan and NR Soelberg. 2014. Off-Gas Treatment Requirements for Used Nuclear Fuel Processing, Presentation at AIChE Annual Meeting, November 17, 2014 Atlanta, GA.

Jubin, R, N Soelberg, and D Strachan. 2013. Iodine Pathways and Off-Gas Stream Characteristics for Aqueous Reprocessing Plants - A Literature Survey and Assessment. Report No. FCRD-SWF-2013000308(ORNL/LTR-2013/383, INL/EXT-13-30119, PNNL-22885), Oak Ridge National Laboratory, Oak Ridge, TN. 
Jubin, R, N Soelberg, D Strachan, and G Ilas. 2011. Assessments and Options for Removal and Immobilization of Volatile Radionuclides from the Processing of Used Nuclear Fuel. Report No. FCR\&D-SWF-2011-000305, Oak Ridge National Laboratory, Oak Ridge, TN.

Jubin, R, N Soelberg, D Strachan, and G Ilas. 2012. Fuel Age Impacts on Gaseous Fission Product Capture During Separations. Report No. FCRD-SWF-2012-000089, PNNL-22550, Oak Ridge National Laboratory, Oak Ridge, TN.

Jubin, RT. 1981. Organic Iodine Removal from Simulated Dissolver Off-Gas Systems Utilizing SilverExchanged Mordenite. Report No. CONF-811108-14, Oak Ridge National Laboratory, Oak Ridge, TN.

Kabat, MJ. 1982. Canadian Nuclear Air Cleaning Standards and Their Application in Ontario Hydro. Report No. IAEA-SR-72/6, International Atomic Energy Agency, Vienna, Austria.

Kabat, MJ. 1981. Chemical Behaviour of Radioiodine under Loss of Coolant Accident Conditions. In Proceedings of the $16^{\text {th }}$ DOE Nuclear Air Cleaning Conference (CONF-801038), 867-90 pp. The Harvard Air Cleaning Laboratory, Cambridge, MA.

Kabat, MJ. 1983. Deposition of Airborne Radioiodine Species on Surfaces of Metals and Plastics. In Proceedings of the 17 $7^{\text {th }}$ DOE/NRC Nuclear Air Cleaning and Treatment Conference, 285-300 pp. The Harvard Air Cleaning Laboratory, Cambridge, MA.

Kabat, MJ. 1974. Testing and Evaluation of Absorbers for Gaseous Penetrative Forms of Radioiodine. In Proceedings of the Thirteenth AEC Air Cleaning Conference, 765-800 pp. The Harvard Air Cleaning Laboratory, Cambridge, MA.

Karhu, A. 2001. Gas Phase Chemistry and Removal of $\mathrm{CH}_{3} I$ During a Severe Accident. Report No. NKS-25, VTT Energy, Vuorimiehentie, Finland.

Keller, JH, FA Duce, and WJ Maeck. 1970a. A Selective Adsorbent. In Proceedings of the Eleventh AEC Air Cleaning Conference (CONF 700816), 621-34 pp. The Harvard Air Cleaning Laboratory, Cambridge, MA.

Keller, JH, FA Duce, DT Pence, and WJ Maeck. 1970b. Hypoiodous Acid: An Airborne Inorganic Iodine Species in Steam-Air Mixtures. In Proceedings of the Eleventh AEC Air Cleaning Conference (CONF 700816), 467-81 pp. The Harvard Air Cleaning Laboratory, Cambridge, MA.

Kulyukhin, SA, AN Kamenskaya, and NA Konovalova. 2011. "Chemistry of Radioactive Iodine in Aqueous Media: Basic and Applied Aspects." Radiochemistry (Moscow, Russ. Fed.) 53(2):123-41. 10.1134/S1066362211020020.

Kulyukhin, SA, AN Kamenskaya, NB Mikheev, IV Melikhov, NA Konovalova, and IA Rumer. 2008. "Basic and Applied Aspects of the Chemistry of Radioactive Iodine in a Gas Medium." Radiochemistry 50(1):1-20. 10.1134/S1066362208010013.

Lee, BS, WA Jester, and JM Olynyk. 1991. "Radioiodine Speciation in the Hot Cell Effluent Gases of a Radiopharmaceutical Production Facility." Health Phys. 61(2):255-8. 10.1097/00004032-19910800000009.

Lin, CC. 1981. "Volatility of Iodine in Dilute Aqueous Solution." J. Inorg. Nucl. Chem. 43(12):3229-38. 10.1016/0022-1902(81)80094-2.

Lovelock, JE, RJ Maggs, and RJ Wade. 1973. "Halogenated Hydrocarbons in and over the Atlantic." Nature (London) 241(5386):194-6. 10.1038/241194a0.

Marrero, TR. 1977. Airborne Release from BWR's for Environmental Impact Evaluations, Amendment 2 $\left({ }^{131} I\right)$. Report No. NEDO-21159-2, General Electric Corporation, Chicago, IL. 
McCracken, DR. 1985. Identification of Iodine Species Released from Fuel Using a Commercial Volatile Radioiodine Species Sampler. In Proceedings of the Annual Conference of the Canadian Nuclear Society, 3.24-3.26 pp. Canadian Nuclear Society, Toronto, Ontario, Canada.

McManus, GJ, FA Duce, SJ Fernandez, and L. P. Murphy. 1982. A Model of Iodine-129 Process Distributions in a Nuclear Fuel Reprocessing Plant. Report No. ENICO-1108, Exxon Nuclear Idaho Company, Idaho Falls, ID.

Milham, RC and LR Jones. 1969. Iodine and Noble Gas Retention Studies Progress Report October 1966-December 1968. Report No. DP-1209, EI du Pont, Aiken, SC.

Mincher, BJ and SP Mezyk. 2009. "Radiation Chemical Effects on Radiochemistry: A Review of Examples Important to Nuclear Power." Radiochim. Acta 97(9):519-34. 10.1524/ract.2009.1646.

Mincher, BJ, G Modolo, and SP Mezyk. 2009. "Review Article: The Effects of Radiation Chemistry on Solvent Extraction: 1. Conditions in Acidic Solution and a Review of TBP Radiolysis." Solvent Extr. Ion Exch. 27(1):1-25. 10.1080/07366290802544767.

Mineo, H, T Kihara, Y Nakano, S Kimura, A Takahashi, T Yagi, G Uchiyama, S Hotoku, M Watanabe, K Kamei, H Hagiya, T Iijima, and S Fujine. 1999a. Dissolution Tests of Spent Fuel in the NUCEF ar Cell Including Dissolver Off-Gas Treatment. In Proceedings of the $2^{\text {nd }}$ NUCEF International Symposium: NUCEF '98: Safety Research and Development of Base Technology on Nuclear Fuel Cycle, 498-507 pp. Japan Atomic Energy Research Institute, Tokai-mura, Japan.

Mineo, H, T Kihara, A Takahashi, T Yagi, Y Nakano, S Kimura, G Uchiyama, S Hotoku, M Watanabe, K Kamei, H Hagiya, T Iijima, and S Fujine. 1999b. Study on Gaseous Effluent Treatment During Dissolution Tests of Spent Fuel. In Proceedings of $W M^{\prime} 99$, 78-83 pp. American Nuclear Society, La Grange Park, IL.

Moore, RM and W Groszko. 1999. "Methyl Iodide Distribution in the Ocean and Fluxes to the Atmosphere." J. Geophys. Res., [Oceans] 104(C5):11163-71. 10.1029/1998JC900073.

Moore, RM and R Tokarczyk. 1992. "Chloro-Iodomethane in N. Atlantic Waters: A Potentially Significant Source of Atmospheric Iodine." Geophys. Res. Lett. 19(17):1779-82. 10.1029/92GL01796.

Morgan, JG and WD Holland. 1980. Iodine Evolution from Nuclear Fuel Dissolver Solutions by Air Sparging. Report No. CONF-800802-18, Oak Ridge National Laboratory, Oak Ridge, TN.

Naba, K and K Imao. 1993. Mixed Incineration System for LLW RIAW and Liquid Scintillator Waste after Storage-for-Decay. In Proceedings of Waste Management '94: Technology and Programs for Radioactive Waste Management and Environmental Restoration, 1649-54 pp. Laser Options, Tucson, AZ.

Nakamura, K, M Saeki, and E Tachikawa. 1973. "Formation of Organic Iodides Upon Heating Nitric Acid Solutions Containing Carrier-Free Iodine-131." Journal of Nuclear Science and Technology 10(6):367-73. 10.1080/18811248.1973.9735435.

Nakhutin, IE, NM Smirnova, GA Laushkina, and GA Loshakov. 1969. "Adsorption of Radioactive Iodine Vapors from the Air." Atomnaya Energiya 26(4):390-1.

Nenoff, TM, MA Rodriguez, NR Soelberg, and KW Chapman. 2014. "Silver-Mordenite for Radiologic Gas Capture from Complex Streams: Dual Catalytic $\mathrm{CH}_{3} \mathrm{I}$ Decomposition and I Confinement." Microporous Mesoporous Materials 200:297-303. 10.1016/j.micromeso.2014.04.041.

O'Neill, M. 2010. System Description for the LAW Primary Offgas (LOP) and Secondary Offgas/Vessel Vent (LVP) Systems. Report No. 24590-LAW-3YD-LOP-00001, Rev. 3, Bechtel, San Francisco, CA. 
Oh, Y, S Bag, CD Malliakas, and MG Kanatzidis. 2011. "Selective Surfaces: High-Surface-Area Zinc Tin Sulfide Chalcogels." Chemistry of Materials 23(9):2447-56.

Paquette, J. 1989. Modeling the Chemistry of Iodine. Report No. AECL-9923, Atomic Energy Canada, Ltd., Pinawa, Canada.

Parsley, LF. 1971. Chemical and Physical Properties of Methyl Iodide and Its Occurance under Reactor Accident Conditions. Report No. ORNL-NSIC-82, Oak Ridge National Laboratory, Oak Ridge, TN.

Pence, DT, FA Duce, and WJ Maeck. 1972. Developments in the Removal of Airborne Iodine Species with Metal Substituted Zeolites. In Proceedings of Twelfth AEC Air Cleaning Conference (CONF-720823), 417-33 pp. The Harvard Air Cleaning Laboratory, Cambridge, MA.

Pence, DT, FA Duce, and WJ Maeck. 1973. Iodine Adsorbent Program, In Idaho Chemical Programs Annual Technical Report Fiscal Year 1972. Report No. ICP-1022, Idaho National Engineering Laboratory, Idaho Falls, ID.

Perez-Ramirez, J, C Mondelli, T Schmidt, OFK Schlueter, A Wolf, L Mleczko, and T Dreier. 2011. "Sustainable Chlorine Recycling Via Catalysed HCl Oxidation: From Fundamentals to Implementation." Energy Environ. Sci. 4(12):4786-99. 10.1039/c1ee02190g.

Rahn, RO. 1991. "Determination of Iodide Formed from Inorganic Iodine in Aqueous Solution." Analytica Chimica Acta 248(2):595-602.

Ravindran, V, M Pirbazari, SW Benson, BN Badriyha, and DH Evans. 1997. "Thermal Destruction of Chlorinated Hydrocarbons by Reductive Pyrolysis." Combust. Sci. Technol. 122(1-6):183-213. $10.1080 / 00102209708935609$.

Reed, WA, I May, FR Livens, JM Charnock, AP Jeapes, M Gresley, RM Mitchell, and P Knight. 2002. "XANES Fingerprinting of Iodine Species in Solution and Speciation of Iodine in Spent Solvent from Nuclear Fuel Reprocessing." Journal of Analytical Atomic Spectrometry 17(5):541-43. 10.1039/b110805k.

Routamo, T. 1996. Effect of Hypoiodous Acid Volatility on the Iodine Source Term in Reactor Accidents. In Proceedings of the Fourth CSNI Workshop on the Chemistry of Iodine in Reactor Safety, 635-53 pp. Paul Scherrer Institute, Würenlingen, Switzerland.

Saiz-Lopez, A, JMC Plane, AR Baker, LJ Carpenter, R von Glasow, JC Gomez Martin, G McFiggans, and RW Saunders. 2012. "Atmospheric Chemistry of Iodine." Chemical Reviews 112(3):1773-804. $10.1021 /$ cr200029u.

Saiz-Lopez, A and R von Glasow. 2012. "Reactive Halogen Chemistry in the Troposphere." Chemical Society Reviews 41(19):6448-72. 10.1039/c2cs35208g.

Sakurai, T, M Izumo, A Takahashi, and Y Komaki. 1983. "Application of Zeolites to Remove Iodine from Dissolver Off-Gas, (I). Follow-up of Wahlgren and Meinke's Experiments." Journal of Nuclear Science and Technology 20(3):264-6. 10.1080/18811248.1983.9733388.

Sakurai, T, M Izumo, A Takahashi, and Y Komaki. 1987. "Behavior of Iodine-131 in Dissolution of Irradiated Uranium Dioxide." Journal of Nuclear Science and Technology 24(11):931-6.

10.1080/18811248.1987.9733524.

Sakurai, T, Y Komaki, A Takahashi, and M Izumo. 1984. "Reactions of Methyl Iodide and Ethyl Iodide with Nitrogen Dioxide on Zeolite 13x." Journal of Nuclear Science and Technology 21(11):877-9. 10.1080/18811248.1984.9731127. 
Sakurai, T, K Komatsu, and A Takahashi. 1997. Behavior of Iodine in the Dissolution of Spent Nuclear Fuels. In Proceedings of the $24^{\text {th }}$ DOE/NRC Nuclear Air Cleaning and Treatment Conference (NUREG/CP-0153; CONF-960715), 550-62 pp. The Harvard Air Cleaning Laboratory, Cambridge, MA.

Sakurai, T, A Takahashi, N Ishikawa, and Y Komaki. 1989. "The Behavior of Iodine in a Simulated Spent-Fuel Solution." Nuclear Technology 85(2):206-12.

Sakurai, T, A Takahashi, N Ishikawa, and Y Komaki. 1995. "Interaction of Iodine with an Extractant of 30\% TBP/70\% N-Dodecane." Journal of Nuclear Science and Technology 32(7):664-70. $10.1080 / 18811248.1995 .9731757$.

Sakurai, T, A Takahashi, N Ishikawa, and Y Komaki. 1990. "The Interaction of Iodine with Insoluble Residue in the Dissolution of Simulated Spent-Fuel Pellets." Nuclear Technology 94:99-107.

Sakurai, T, A Takahashi, N Ishikawa, Y Komaki, and M Ohnuki. 1996. "Influence of NOx and HNO2 on Iodine Quantity in Spent-Fuel Solutions." Nuclear Technology 116(3):319-26.

Sakurai, T, A Takahashi, N Ishikawa, Y Komaki, M Ohnuki, and T Adachi. 1992. "The Iodine Species and Their Behavior in the Dissolution of Spent-Fuel Specimens." Nuclear Technology 99(1):70-9.

Sakurai, T, A Takahashi, N Ishikawa, Y Komaki, M Ohnuki, and T Adachi. 1993. "Thermochemical and Experimental Considerations of Nitrogen Oxide (NOx) Composition and Iodine Species in the Dissolution of Spent PWR-Fuel Specimens." Journal of Nuclear Science and Technology 30(6):533-41. 10.1080/18811248.1993.9734515.

Scheele, RD, LL Burger, and CL Matsuzaki. 1983. Methyl Iodide Sorption by Reduced Silver Mordenite. Report No. PNL-4489, Pacific Northwest National Laboratory, Richland, WA.

Schindler, RE. 1981. Incineration of Contaminated Organic Solvents in a Fluidized-Bed Calciner. In Proceedings of the $16^{\text {th }}$ DOE Nuclear Air Cleaning Conference (CONF-801038), 950-58 pp. The Harvard Air Cleaning Laboratory, Cambridge, MA.

Schwehr, KA, S Otosaka, S Merchel, DI Kaplan, S Zhang, C Xu, H-P Li, Y-F Ho, CM Yeager, and PH Santschi. 2014. "Speciation of Iodine Isotopes Inside and Outside of a Contaminant Plume at the Savannah River Site." Science of the Total Environment 497-498:671-78.

10.1016/j.scitotenv.2014.07.006.

Schwehr, KA and PH Santschi. 2003. "Sensitive Determination of Iodine Species, Including OrganoIodine, for Freshwater and Seawater Samples Using High Performance Liquid Chromatography and Spectrophotometric Detection." Analytica Chimica Acta 482(1):59-71. 10.1016/S0003-2670(03)00197-1.

Schwehr, KA, PH Santschi, and D Elmore. 2005. "The Dissolved Organic Iodine Species of the Isotopic Ratio of 129I/127I: A Novel Tool for Tracing Terrestrial Organic Carbon in the Estuarine Surface Waters of Galveston Bay, Texas." Limnology and Oceanography: Methods 3:326-37. 10.4319/1om.2005.3.326.

Schwehr, KA, PH Santschi, DI Kaplan, CM Yeager, and R Brinkmeyer. 2009. "Organo-Iodine Formation in Soils and Aquifer Sediments at Ambient Concentrations." Environmental Science and Technology 43(19):7258-64. 10.1021/es900795k.

Seki, K. 2010. "Development of RuO2/Rutile-TiO2 Catalyst for Industrial HCl Oxidation Process." Catal. Surv. Asia 14(3-4):168-75. 10.1007/s10563-010-9091-7.

Singh, HB, LJ Salas, and RE Stiles. 1983. "Methyl Halides in and over the Eastern Pacific (40 $\left.\mathrm{N}-32^{\circ} \mathrm{S}\right) . "$ Journal of Geophysical Research, C: Oceans and Atmospheres 88(C6):3684-90.

Soelberg, NR, AG Chambers, JD Grandy, KJ Liekhus, and GL Anderson. 1997. Metals, Particulate, and Radionuclide Partitioning Results from Mixed Waste Thermal Treatment Demonstrations. In Proceedings 
of the 1997 International Conference on Incineration and Thermal Treatment Technologies, 769-82 pp. University of California, Irvine, Irvine, CA.

Solomon, S, RR Garcia, and AR Ravishankara. 1994. "On the Role of Iodine in Ozone Depletion." Journal of Geophysical Research, [Atmospheres] 99(D10):20,491-9. 10.1029/94JD02028.

Soo Hoo, GY, C-C Lin, RM Norris, and CD Wilkinson. 1975. "Performance of Silver Zeolite in a Radioiodine Monitor." IEEE Transaction of the Nuclear Society 22(1):657-60.

10.1109/TNS.1975.4327724.

Sturges, WT and LA Barrie. 1988. "Chlorine, Bromine and Iodine in Arctic Aerosols." Atmospheric Environment 22(6):1179-94. 10.1016/0004-6981(88)90349-6.

Šulková, K, J Federič, F Louis, L Cantrel, L Demovič, and I Černušák. 2013. "Thermochemistry of Small Iodine Species." Physica Scripta 88(5):058304-11. 10.1088/0031-8949/88/05/058304.

Tachikawa, E. 1973. "Formation and Control of Radioactive Organic Iodine." Genshiryoku Kogyo 19(12):50-2, 76.

Taghipour, F. 1999. "The Impact of Organic Compounds on Iodine Behaviour under Conditions Relating to Nuclear Reactor Accidents." University of Toronto, Toronto, Canada: Nuclear Engineering. Ph.D. Doctoral Dissertaion.

Tripathi, SC, S Sumathi, and A Ramanujam. 1999. "Effects of Solvent Recycling on Radiolytic Degradation of 30\% Tributyl Phosphate-N-Dodecane-HNO3 System." Sep. Sci. Technol. 34(14):2887-903. 10.1081/SS-100100811.

Vienna, JD, ED Collins, CJ V, WL Ebert, SM Frank, TG Garn, D Gombert II, RH Jones, RT Jubin, VC Maio, JC Marra, J Matyáš, TM Nenoff, BJ Riley, GJ Sevigny, NR Soelberg, DM Strachan, PK Thallapally, and JH Westsik, Jr. 2015. Closed Fuel Cycle Waste Treatment Strategy. Report No. FCRD-MRWFD-2015-000674, Rev. 0 (PNNL-24114), Pacific Northwest National Laboratory, Richland, WA.

Vienna, JD and RD Scheele. 2012. Discussion Points on Silver Mordenite Column Design for Hanford Tank Waste Treatment and Immobilization Plant. Presented at the JNFL, DOE, National Laboratory and AREVA Technical Exchange on Fission Gas Capture and Stabilization, Pacific Northwest National Laboratory, Richland, WA.

Vogt, R, R Sander, R Von Glasow, and PJ Crutzen. 1999. "Iodine Chemistry and Its Role in Halogen Activation and Ozone Loss in the Marine Boundary Layer: A Model Study." Journal of Atmospheric Chemistry 32(3):375-95.

Wang, X-t, Y-z Jiao, B-s Jin, B Xu, P-j Mao, and J Wu. 2007. "Melting Characteristics of Fly Ashes from Co-Firing of Municipal Solid Waste and Coal Incinerator." Ranshao Kexue Yu Jishu 13(1):35-39.

Wershofen, H and DC Aumann. 1989. "Iodine-129 in the Environment of a Nuclear Fuel Reprocessing Plant: VII. Concentrations and Chemical Forms of ${ }^{129} \mathrm{I}$ and ${ }^{127} \mathrm{I}$ in the Atmosphere." Journal of Environmental Radioactivity 10(2):141-56. 10.1016/0265-931X(89)90011-8.

Whitehead, DC. 1984. "The Distribution and Transformations of Iodine in the Environment." Environment International 10(4):321-39. 10.1016/0160-4120(84)90139-9.

Wikström, E and S Marklund. 2000. "Secondary Formation of Chlorinated Dibenzo-P-Dioxins, Dibenzofurans, Biphenyls, Benzenes, and Phenols During MSW Combustion." Environmental Science and Technology 34(4):604-09. 10.1021/es9906498. 
Wilhelm, JG, J Furrer, and E Schultes. 1977. Head-End Iodine Removal from a Reprocessing Plant with a Solid Sorbent. In Proceedings of the Fourteenth ERDA Air Cleaning Conference, 447-77 pp. The Harvard Air Cleaning Laboratory, Cambridge, MA.

Wilhelm, JG and H Schuttelkopf. 1970. Inorganic Adsorber Materials for Trapping of Fission Product Iodine. In Proceedings of the Eleventh AEC Air Cleaning Conference, 568-80 pp. The Harvard Air Cleaning Laboratory, Cambridge, MA.

Wren, DJ, J Paquette, JC Wren, PN Clough, and BC Starkie. 1987. A Review of Iodine Chemistry under Severe Accident Conditions. Report No. AECL-9089, Whiteshell Nuclear Research Establishment, Pinawa, Canada.

Wren, JC, JM Ball, and GA Glowa. 1999. "The Interaction of Iodine with Organic Material in Containment." Nuclear Technology 125(3):337-61.

Wren, JC, J Paquette, DJ Wren, and GG Sanipelli. 1986. The Formation and Volatility of Organic Iodides. Report No. AERE-R-11974, Whiteshell Nuclear Research Establishment, Harwell, UK.

Wright, A and P Paviet-Hartmann. 2010. "Review of Physical and Chemical Properties of Tributyl Phosphate/Diluent/Nitric Acid Systems." Sep. Sci. Technol. 45(12-13):1753-62. 10.1080/01496395.2010.494087.

Yang, X, L Sun, J Xiang, S Hu, and S Su. 2013. "Pyrolysis and Dehalogenation of Plastics from Waste Electrical and Electronic Equipment (WEEE): A Review." Waste Manag. 33(2):462-73.

Yoshida, S and Y Muramatsu. 1995. "Determination of Organic, Inorganic and Particulate Iodine in the Coastal Atmosphere of Japan." Journal of Radioanalytical and Nuclear Chemistry 196(2):295-302. 10.1007/BF02038047.

Zhang, LY and XL Hou. 2013. "Speciation Analysis of I-129 and Its Applications in Environmental Research." Radiochimica Acta 101(8):525-40. 10.1524/ract.2013.2077. 